\title{
O SUPREMO TRIBUNAL FEDERAL E O ESTADO DE SITTIO NA REPÚBLICA VELHA: A JURISPRUDENCIA DO SUPREMO TRIBUNAL FEDERAL SOBRE O ESTADO DE SÍTIO, DO INÍCIO DA REPÚBLICA ATÉ A REVOLUÇÃO DE 30 (1893-1930).
}

\section{Rodrigo Luz Peixoto ${ }^{1}$}

\begin{abstract}
Resumo
Este trabalho tem por tema a jurisdição constitucional sobre estado de sítio no Brasil ao longo da República Velha. A pergunta se coloca quanto a possibilidade de encontrar uma linha que dê unidade à compreensão do estado de sítio na jurisprudência do Supremo Tribunal Federal no período entre 1891 e 1930. A metodologia é indutiva, pela análise de decisões selecionadas do tribunal para buscar, a partir dos casos específicos, um entendimento geral da jurisprudência constitucional. Tinha-se por hipótese que o Supremo Tribunal Federal manteve linha única na sua jurisprudência durante o período analisado, exercendo controle sobre a constitucionalidade da declaração e exercício do Estado de sítio. Tal hipótese veio a se confirmar parcialmente, chegando ao resultado de que a jurisprudência sobre estado de sítio passa por uma progressiva evolução, ao longo do período, até uma concepção restrita da questão política e uma postura protetora dos direitos e garantias individuais. Em considerações finais, o presente estudo contribui para a compreensão da relação entre estado de sítio e direitos fundamentais na tradição brasileira.
\end{abstract}

Palavras-chave: República Velha. Estado de Sítio. Supremo Tribunal Federal. Brasil. Questão Política.

\section{INTRODUÇÃO}

Este trabalho aborda a questão do estado de sítio desde um panorama histórico-jurídico, reconstruindo os desenvolvimentos da jurisprudência do Supremo Tribunal Federal (STF) entre 1891 e 1926. O estado de sítio, como forma de regulamentar constitucionalmente o estado de exceção, é uma temática fundamental no Direito Constitucional, sobretudo diante de afirmações recentes sobre a transformação do estado de exceção em paradigma permanente de governo no Estado moderno (AGAMBEN, 2010; FRIEDRICH, 1968, p. 570). Para avaliar semelhantes afirmações, é necessário a reconstrução da origem dos institutos normativos que regulamentam a exceção constitucionalmente, para inserir o debate no contexto de cada tradição constitucional. No caso, esse trabalho se volta para a tradição constitucional brasileira. A metodologia que se utiliza é indutiva,

\footnotetext{
${ }^{1}$ Mestrando pelo Programa de Pós-Graduação em Direito da Universidade Federal do Rio Grande do Sul. Bolsista CAPES. Email: rodrigo.luz.peixoto@gmail.com
} 
para elencar e analisar a jurisprudência do STF ao longo do período da República Velha para se obter uma compreensão histórica da linha de decisão adotada por este tribunal nos primeiros momentos da república.

A escolha da jurisprudência do STF se deve ao fato de que este tribunal é, no período analisado, um tribunal com atribuições constitucionais e a última instância de decisão judicial nacional, representando, portanto, a interpretação constitucional mais relevante no campo judicial, para o momento analisado. Tanto mais na medida em que o período analisado representa a época de consolidação do STF como instituição constitucional relevante no Brasil.

A escolha do marco temporal também se justifica metodologicamente na medida em que a Constituição de 1891 é o momento inaugural do estado de sítio como regulação do estado de exceção no Brasil. A Constituição imperial, apesar de conter provisões emergenciais, não delimita de maneira tão precisa os procedimentos quanto o faz a primeira Constituição republicana com o estado de sítio, de modo que esta pode ser considerada o ponto de partida dessa forma de regulamentação constitucional da exceção no Brasil.

Por isso, o trabalho aqui desenvolvido se ocupará apenas da jurisprudência do STF e da prática normativa do estado de sítio no período entre 1891 e 1930, delimitado o início pela promulgação da Constituição de 1891 e o fim pela ascensão do governo provisório de Getúlio Vargas com a Revolução de 30, o qual termina por revogar a Constituição de 1891 por meio da criação da Constituição de 1934, a qual inicia uma nova etapa na história brasileira, inclusive jurídico constitucionalmente. Os acórdãos escolhidos foram selecionados a fim de refletirem episódios e momentos historicamente relevantes para o desenvolvimento das instituições durante o período analisado. Resta assim definida a metodologia, adequada a perseguir o objetivo apontado, qual seja, a descrição da evolução da linha jurisprudencial do Supremo Tribunal Federal sobre o estado de sítio sob a Constituição de 1891.

\section{REGULAMENTAÇÃO DO ESTADO DE SÍTIO NA CONSTITUIÇÃO BRASILEIRA DE 1891}

O estado de sítio é uma das espécies de regulamentação de estado de exceção, também categorizado como uma forma de Ditadura Constitucional (FRIEDRICH, 1968, p. 561). A função de um estado de exceção é permitir meios excepcionais para se afastarem determinados perigos sérios à ordem pública, segurança ou existência do Estado que não possam ser afastados pelos caminhos normais da Constituição (HESSE, 1998, p. 526). Assim, o estado de sítio é uma forma pela qual uma Constituição regulamenta o exercício de poderes excepcionais em meio a uma emergência para proteger o Estado, a ordem ou a segurança pública. A forma do estado de sítio se difere de outras formas de estado de exceção: por ser declarado explicitamente, pelo Legislativo ou outro dos ramos do governo, e por ter como consequência principal a suspensão de certas garantias ou direitos 
fundamentais especificamente estabelecidos. A expressão "estado de sítio" se origina da tradução do instituto francês do état de siége, instituto criado, por decreto da Assembleia Nacional em 1791, para situações de ameaça militar, mas que se expandiu ao longo do tempo para além do âmbito bélico “(...) para ser usado como medida extraordinária de polícia frente a desordens e sedições internas, transformando-se assim de efetivo ou militar em fictício ou político" (AGAMBEN, 2010, p. 29, trad.livre). No Brasil, surge pela primeira vez na Constituição da República de 1891.

A regulamentação para o estado de sítio na Constituição de 1891 estabelecia regras claras de competência. A competência para a declaração do estado de sítio era, primeiramente, privativa do Congresso Nacional (Art. 34, item 21). ${ }^{2}$ Entretanto, previa-se a possibilidade excepcional de ser declarado o estado de sítio pelo Poder Executivo, apenas quando na ausência do Congresso (como se observa na leitura do art. 48, item 15, combinado ao art. 34, item 21). No caso da declaração do sítio pelo Presidente, em pessoa ou por meio de seus agentes responsáveis, deve o Presidente, tão logo seja reunido o Congresso, relatar e motivar as medidas de exceção tomadas pelo Executivo (art. 80, $\$ 3^{\circ}$ ). As autoridades que ordenavam tais medidas podiam ser responsabilizadas por abusos cometidos nas medidas (art. 80, $\$ 4^{\circ}$ ).

A situação que ensejava o sítio era a "emergencia de aggressão por forças estrangeiras ou de commoção interna" (art. 34, item 21), de modo que ficava a cargo do órgão declarante (Congresso ou, subsidiariamente, Executivo) a interpretação da expressão "comoção interna", semanticamente pouco clara. A abertura semântica da expressão, entretanto, está alinhada com o propósito da regulamentação da exceção, uma vez que é muito difícil prever com exatidão o tipo de emergência que pode vir a desafiar os meios constitucionalmente previstos para a defesa da própria Constituição. Assim, a Agressão Estrangeira e a Comoção Interna (ou "intestina", como colocada no art. 48, 15) se configuram como as duas situações fáticas capazes de ensejar a consequência da declaração do estado de sítio, com seus respectivos efeitos jurídicos.

São os efeitos da declaração de estado de sítio na Constituição de 1891: Competência do Congresso para determinar a suspensão de quaisquer garantias por tempo determinado, a competência excepcional do Executivo para impor "detenção em lugar não destinado aos réus de crimes comuns" e para impor "desterro a outros sítios do território nacional". A emenda constitucional de 3 de setembro de 1926 adicionou mais um efeito, pela inclusão de um parágrafo ao artigo 60 da Constituição de 1891, qual seja, a proibição colocada ao Judiciário de conhecer de ações motivadas pelos atos praticados pelo Legislativo e Executivo em virtude do estado de sítio (art. 60, $\left.\$ 5^{\circ}\right)$.

Todas as constituições posteriores mantiveram alguma regulamentação sob a forma e o nome de estado de sítio, exceto na Constituição de 1937, que previa os institutos do estado de emergência e do estado de guerra,

\footnotetext{
${ }^{2}$ Após a emenda constitucional de 03 de setembro de 1926, ficou com a mesma redação, mas no art. 34, item 20.
} 
diferenciados do sítio sobretudo pela competência exclusiva do Presidente, independente de autorização do Legislativo, e não podendo o Congresso suspender o estado de emergência. Nas constituições de 1934 e 1946, a previsão de regulamentação do estado de sítio manteve-se muito similar àquela da Constituição de 1891 . De qualquer modo, ao longo da vigência das Constituições que previam o estado de sítio, coube ao Supremo Tribunal dirimir questões jurídicas que envolviam o estado de sítio. ${ }^{3}$

Com isso, notamos que a Constituição de 1891 teve efeitos significativos na tradição constitucional brasileira, na temática do estado de sítio, vindo a afetar fortemente as constituições seguintes. Por isso, seguimos o presente trabalho, passando à análise das decisões do STF sobre o estado de sítio sob a Constituição de 1891. Dado que se pretende apresentar a questão sob perspectiva histórica, ao invés de sistematizar a análise de maneira temática, os acórdãos são analisados em ordem cronológica, de acordo com a data de julgamento.

\section{O PAPEL DO JUDICIÁRIO FRENTE A EXCEÇÃO: O PAPEL DO HABEAS CORPUS NA REVOLTA DA ARMADA E AS DECISÕES DO CASO JÚPITER}

Em 1892, a regulamentação do Estado de Sítio na Constituição de 1891 foi colocada em questão pela primeira vez. O Executivo, à época sob comando do então Vice-Presidente Marechal Floriano Peixoto, havia declarado o Distrito Federal em estado de sítio, por meio do Decreto no 791 de 10 de Abril de 1892, como resposta à Revolta da Armada, rebelião causada por motins de militares da Marinha Nacional, que tomaram navios de guerra e exigiam a saída de Floriano Peixoto do cargo da presidência com a convocação de novas eleições (uma vez que Hermes da Fonseca havia renunciado do cargo de Presidente e Floriano assumiu como vice sem convocar novas eleições). ${ }^{4}$ Entendendo como configurada a situação de comoção intestina prevista na Constituição, Floriano editou o decreto com a seguinte redação:
Declara em estado de sitio o Districto Federal e suspende as garantias por 72 horas.
O Vice-Presidente da Republica dos Estados Unidos do Brazil, considerando: que foi commettido o crime de sedição, sahindo cidadãos a depor o Chefe do Governo Federal;
que intentou-se revoltar contra as instituições nacionaes a força armada mantida para a defesa e garantia dessas mesmas instituições;
que entre os autores e promotores da sedição se acham membros do Congresso Nacional, que gosam de immunidades por lei prescriptas;

\footnotetext{
${ }^{3}$ Note-se que o STF nunca chegou a decidir sobre o estado de emergência nos moldes da Constituição de 1937. Esta constituição previa a impossibilidade aos juízes e tribunais de conhecerem dos atos praticados em virtude do estado de emergência enquanto este estivesse em vigor (art. 170, Constituição de 1937). Provavelmente, como houve apenas um ano entre o fim da emergência e a nova Constituição, nenhuma demanda envolvendo o dispositivo da emergência chegou ao STF.

${ }^{4}$ A controvérsia havia sido agravada pelo Manifesto dos Treze Generais, documento assinado por oficiais militares de diversas partes do país, que contestavam a continuidade de Floriano na Presidência, entendo que cabiam novas eleições, haja visto o art. 42 da Constituição de 1891, o qual estabelece: "Se no caso de vaga, por qualquer causa, da Presidência ou Vice-Presidência, não houverem ainda decorrido dois anos do período presidencial, proceder-se-á a nova eleição” (SILVA e CARNEIRO, 1975b, p. 111-115).
} 
que o crime commettido produziu grave commoção intestina (art. $48 \mathrm{n}$. 15 e art. $80 \$ 1^{\circ} \mathrm{da}$ Constituição Federal);

que é principal dever do Poder Executivo assegurar a ordem e a manutenção das instituições nacionaes; Resolve, usando das attribuições conferidas pelos citados artigos,

Decretar:

Artigo unico. É declarado em estado do [sic] sitio o Districto Federal e suspensas as garantias constitucionaes, por 72 horas.

O Ministro de Estado dos Negocios do Interior o faça executar.

Com base nessa declaração de sítio, o Vice-Presidente Floriano Peixoto determinou a detenção e o desterro de várias pessoas, tidas pelo governo como de algum modo envolvidas na Revolta, mantendo os detidos presos em fortalezas. O advogado Rui Barbosa assumiu para si a tarefa de defender vários dentre os afetados pelas medidas, ingressando com uma série de petições de Habeas Corpus perante o Supremo Tribunal Federal, tendo os detidos como pacientes. Nesses Habeas Corpus, de número 300, 406, 410, 415, Ruy Barbosa questiona juridicamente as medidas tomadas pelo Executivo, provocando o Judiciário a se posicionar sobre a interpretação das normas constitucionais vigentes que regulavam o estado de sítio. O supremo também se manifestou sobre a matéria no HC 1073, colocado por outros impetrantes, mas em defesa de pacientes que também estavam envolvidos no HC 1063.

Posteriormente, o desenrolar dos casos levaria Ruy Barbosa a patrocinar ações civis em favor dos reformados e demitidos pelo governo, contra um decreto de 12 de abril de 1892, editado em meio a este estado de sítio como retaliação do governo contra aqueles que julgava envolvidos na Revolta. A peça apresentada por Ruy perante o Supremo Tribunal Federal, no curso dessa ação, foi editada como livro, tornando-se uma obra clássica do Direito Constitucional brasileiro (BARBOSA, 2010).

O primeiro Habeas Corpus, de no 300, foi julgado em 30 de abril de 1892. No acórdão, o relator toma posição sobre uma série de questões que se colocavam à interpretação pelo tribunal. De início, deve notar-se que, nesse acórdão, o Supremo Tribunal Federal decidiu qual era a natureza das medidas que podiam ser tomadas pelo Presidente durante o estado de sítio (detenção em local distinto dos réus de crimes comuns e desterro):

Considerando que durante o estado de sítio é autorizado o Presidente da República a impor, como medida de repressão, a detenção em lugar não destinado aos réus de crimes comuns e o desterro para outros sítios do território nacional;

Considerando que estas medidas não revestem o caráter de pena, que o Presidente da República em caso algum poderá impor, visto não lhe ter sido conferida a atribuição de julgar, mas são medidas de segurança, de natureza transitória, enquanto os acusados não são submetidos aos seus juízes naturais nos termos do art. $72, \mathbb{} 15$ da Constituição (BRASIL, STF, HC300, p.1);

Assim, encaixa-se a detenção prevista no estado de sítio em uma categoria de "medida de segurança", uma vez que a imposição de pena demandava formalidades e garantias legais que não eram concedidas na 
situação do sítio. Tal interpretação faz sentido, na medida em que se entenda que o sítio afasta determinadas garantias expressas e que a pena só possa decorrer de um processo criminal que siga as formalidades das garantias.

O que causou maior polêmica na jurisprudência do Supremo Tribunal Federal, entretanto, seria o que podemos chamar de "Doutrina da Questão Política". Interpretando as faculdades conferidas ao Presidente durante o estado de sítio, o relator do acórdão considerou-as como sendo discricionárias do Presidente da República, que se torna responsável pela declaração e pelos eventuais abusos cometidos no estado de sítio. Quanto à discricionariedade, é fato que nunca se chegou a questionar na história constitucional do instituto, e é necessário algum grau de discricionariedade à atribuição de qualquer funcionário público, em virtude de que este atua sempre dentro de um quadro normativo, criando e aplicando normas. Entretanto, o Supremo Tribunal Federal decidiu que essa discricionariedade implicava que as questões surgidas do uso das faculdades do Executivo no estado de sítio não podiam ser resolvidas pelo Judiciário, pois dependiam sempre de um juízo político prévio. Assim, no Habeas Corpus 300, consideravam a avaliação das medidas de sítio do Executivo pelo Congresso Nacional como juízo político que impedia um juízo jurídico:

Considerando, porém, que o exercício desta extraordinária faculdade a Constituição confiou ao critério e prudente discrição do Presidente da República, responsável por ela, pelas medidas de exceção que tomar, e pelos abusos que à sombra delas possa cometer;

Considerando que, pelo art. 80, $\mathbb{\$} 3^{\circ}$, combinado com o art. 34, $\$ 21$ da Constituição, ao Congresso compete privativamente aprovar ou reprovar o estado de sítio declarado pelo

Presidente da República, bem assim o exame das medidas excepcionais, que ele houver tomado, as quais para esse fim the serão relatadas com especificação dos motivos em que se fundam;

Considerando, portanto, que, antes do juízo político do Congresso, não pode o Poder Judicial apreciar o uso que fez o Presidente da República daquela atribuição constitucional, e que, também, não é da índole do Supremo Tribunal Federal envolver-se nas funções políticas do Poder Executivo ou Legislativo;

Considerando que, ainda quando na situação criada pelo estado de sítio, estejam ou possam estar envolvidos alguns direitos individuais, esta circunstância não habilita o Poder Judicial a intervir para nulificar as medidas de segurança decretadas pelo Presidente da República, visto ser impossível isolar esses direitos da questão política, que os envolve e compreende, salvo se unicamente tratar-se de punir os abusos dos agentes subalternos na execução das mesmas medidas, porque a esses agentes não se estende a necessidade do voto político do Congresso (BRASIL, STF, HC300, p.1-2);

Assim, o Supremo Tribunal Federal buscava excluir as decisões jurídicas sobre o estado de sítio de sua competência, por tratar-se de uma suposta questão política. Tal jurisprudência encontraria um forte contraponto na arguição que Ruy Barbosa faria nas ações civis dos reformados e demitidos pelos decretos de 7 e 12 de abril de 
1892. Sobre o ponto, Ruy Barbosa deixa claro que a previsão de um juízo político não impede que ocorra também um juízo jurídico-constitucional. Explicando a questão política, o autor apresenta duas acepções para a expressão "questão política": uma acepção ampla, que acabaria abrangendo toda a soberania constitucional, e uma acepção restrita, em que a questão política o é "pela natureza do assunto, pela forma que a controvérsia assumir, pelos termos em que a resolverem" (BARBOSA, 2010, p. 103). Muito brevemente, questões políticas no sentido estrito, esclarece Barbosa, é a que versa sobre a conveniência ou oportunidade de exercitar os poderes que a constituição confere a um determinado cargo (BARBOSA, 2010, p. 102). Entretanto, quando a questão é se o ato praticado pelo detentor de um cargo público estava dentro das competências e faculdades que a lei prescreve ao cargo, a questão será jurídica, pois não diz respeito a conveniência ou oportunidade (onde a autoridade tem seu poder discricionário), mas diz respeito justamente à ausência de um tal poder discricionário à autoridade. Assim, a fundamentação do Habeas Corpus 300 pela "Doutrina da Questão Política", na medida em que exige o juízo político do Congresso como condição para realizar juízos jurídicos sobre a competência e alcance constitucional de medidas do Executivo, apresenta grave falha. Confunde os dois tipos de juízo, pois o Congresso não pode aprovar o uso feito pelo Presidente de uma determinada competência, se o Presidente não a tem. Não se trata de uma mesma avaliação, que caiba ao Judiciário ou ao Legislativo, mas de duas avaliações distintas. O juízo político coloca a pergunta: O Presidente usou de maneira oportuna e conveniente os poderes de sítio a ele conferidos? $\mathrm{O}$ juízo jurídico (constitucional, no caso) coloca a pergunta: "As medidas que o Presidente ordenou estão incluídas nos poderes de sítio a ele conferidos"? O juízo jurídico, portanto, é técnico, dependendo da interpretação adequada do texto constitucional. Essa interpretação jurídica demanda um saber técnico, que só é adquirido às custas do estudo dedicado do Direito. ${ }^{5}$ Deste modo, diferem fundamentalmente os juízos político e jurídico. O juízo político pode ser exercido por qualquer representante, independente do conhecimento deste acerca do Direito, porque é um juízo de conveniência. O juízo jurídico, diferentemente, só pode ser exercido por um juiz competente, que tenha o conhecimento do Direito para poder delimitar, por meio da interpretação constitucional, o quadro normativo das medidas permitidas, de maneira clara e fundamentada. Assim, inaugurouse nesse acórdão do HC 300 uma restrição indevida do acesso ao tribunal, por meio da afirmação dessa doutrina da questão política, que acabou por impedir o pleno exercício da jurisdição constitucional sobre os abusos cometidos no estado de sítio, ao submeter o exercício desta a uma decisão do Congresso que não era jurídica, mas sim política. Assim, na prática, a jurisprudência do STF deixava o direito individual dos cidadãos na dependência de uma decisão de conveniência do Congresso, que nada tinha de técnico-jurídica.

\footnotetext{
${ }^{5} \mathrm{O}$ que significa dizer que não é uma "razão natural", que surge com o simples nascimento, mas sim que é uma "razão artificial", adquirida pelo melhoramento da razão pelo estudo e pela técnica. A doutrina da "razão artificial" foi desenvolvida justamente na Inglaterra, como forma de afirmar que o juiz estava sob a lei, nunca acima da lei, e que não cabia a ele a adequada interpret ação dos estatutos, por não ser versado no direito inglês com o mesmo estudo que os juízes (FRIEDRICH, 1968, p. 104-107).
} 
A outra questão que se distingue no acórdão do HC300 é acerca da duração das medidas tomadas durante o estado de sítio. O tribunal decidiu que as medidas tomadas na duração do estado de sítio não devem cessar automaticamente com o fim do estado de sítio, mas que se prolongam além desta cessação, pelo menos até o acusado ser submetido ao tribunal competente. No acórdão:

Considerando, finalmente, que a cessação do estado de sítio não importa, ipso facto, na cessação das medidas tomadas dentro dele, as quais continuam a subsistir, enquanto os acusados não forem submetidos, como devem, aos tribunais competentes, pois do contrário, poderiam ficar inutilizadas todas as providências aconselhadas em tal emergência por graves razões de ordem pública (BRASIL, STF, HC300, p.2);

A questão voltaria a ser confrontada na jurisprudência futura do tribunal, visto que tal interpretação tem dificuldades muito mais profundas de fundamentação. Em primeiro lugar, há um problema de coerência entre dois pontos da decisão: por um lado, o STF reconhece que a detenção determinada pelo Presidente da República não tem o caráter de uma pena criminal, enquanto por outro lado, implica que essa medida, sem caráter penal, se torne uma prisão preventiva, como se o detido necessariamente devesse tornar-se réu de ação penal (o que o tribunal dá a entender ao usar o termo "acusado" para referir-se ao paciente). Se soma a isso a doutrina da questão política, impedindo o Habeas Corpus ao STF, o que resulta na interpretação da medida de detenção no sítio em um sentido tal que cria um instituto jurídico em que o detido tem sua liberdade de locomoção restrita, mas sem que isto implique o caráter de pena, aguardando um julgamento, sendo que foi detido não por um crime propriamente dito, mas por decisão discricionária do Presidente da República, e que depende de uma decisão política do Congresso para poder ser julgado e ter acesso a garantia fundamental do Habeas Corpus. E essa situação já com a ordem constitucional restaurada à normalidade, vez que cessada a situação que levou a repressão. Tal interpretação deixou o direito individual fundamental do detido no sítio totalmente dependente de juízos políticos. Ou seja, se o Presidente da República julgasse conveniente, mandava deter (o que implica, por conseguinte, em uma acusação criminal, a julgar pela terminologia adotada pelo STF) e, se o Congresso não se manifestasse, continuaria detido indefinidamente, ainda que sem pena alguma, até o Congresso decidir a conveniência dos atos do Presidente durante o sítio.

Ponto de fundamentação mais breve, mas que veio a causar grande efeito nas discussões seguintes do STF sobre estado de sítio, dizia respeito à duração das medidas tomadas dentro do estado de sítio. No acórdão do HC 300, o voto vencedor afirmava que as medidas tomadas no estado de sítio não se encerravam automaticamente com a cessação do estado de sítio.

Tal decisão carrega em si uma fundamentação simples, mas que acabou se tornando a solução para uma controvérsia complexa. A duração das medidas tomadas no estado de exceção não era explicitamente colocada na Constituição de 1891. Assim, confrontados com detenções, determinadas no decreto que declarava o sítio, que 
ainda perduravam após o fim da situação de sítio, os ministros do STF tiveram que dar resposta a seguinte pergunta: a detenção deve cessar imediatamente com o fim do estado de sítio ou a detenção pode se prolongar, mesmo depois de restaurada a normalidade constitucional? A resposta de tal pergunta, obviamente, é central à decisão do caso, uma vez que, no caso de a detenção cessar junto com o estado de sítio, a detenção perderia seus fundamentos e deveriam ser soltos os detidos. Entretanto, o STF decidiu que as medidas tomadas no estado de sítio se prolongam além da cessação do estado de sítio, até os detidos serem submetidos aos tribunais competentes. Aqui, novamente, a detenção aparece como preventiva, sem revestir o caráter de penalidade, mas atrelada a um possível processo criminal. Ao que tudo indica, portanto, o sentido da detenção no estado de sítio que está presente nesse acórdão é a ideia de que a detenção configura uma medida política e discricionária do Presidente da República, decretada em um estado de sítio, pelo qual o detido é privado da liberdade de locomoção sem as garantias do devido processo legal, para ser futuramente submetido a um processo criminal e decidida, apenas ao fim deste, a transformação da detenção em pena ou o livramento do detido. Para chegar ao livramento, portanto, é necessário que ocorram todos os seguintes fatos: (1) o fim da comoção intestina e a cessação do estado de sítio, (2) o juízo político do Congresso, antes do qual o Judiciário não poderia decidir e (3) a apresentação do detido a um tribunal competente.

Os tribunais competentes para a decisão sobre a detenção não são explicitados na Constituição, nem tampouco nesse acórdão. Entretanto, o Habeas Corpus 415, ao decidir questões de competência e de indivisibilidade de juízo, deixa entrever que as regras de competência seriam as da legislação penal vigente, sendo a detenção tratada como uma medida temporária anterior à uma decisão de caráter verdadeiramente penal.

O único voto divergente na decisão do HC 300 foi o voto do ministro Piza e Almeida. Ele interpretou o regimento interno do STF, no seu art. $65, \$$ 30: "O tribunal se declarará incompetente para conceder a ordem [...] se a coação proceder de autoridade militar, no exercício privativo de suas atribuições contra outro militar ou cidadão sujeito no regímen militar (Dec. n. 848 de 11 de outubro de 1890, art. 47), ou se tratar-se de medida de repressão autorizada pelo art. 80 da Constituição de 1891, enquanto perdurar o estado de sítio”. Assim, Piza e Almeida interpreta, a contrario sensu, que se o regimento determina que o tribunal é incompetente enquanto perdurar o estado de sítio, isso implica que, uma vez cessado o sítio, ele seria competente para conceder a ordem.

Além desse fundamento, baseado em uma interpretação textual, divergiu no sentido de conceder a ordem baseando em um fundamento histórico. Uma vez que não havia lei regulamentando o art. 80 da Constituição de 1891, voltou-se à tradição sob a Constituição anterior para buscar antecedentes que guiassem a interpretação. O ministro Piza e Almeida referiu ao art. 179, XXXV da Constituição Imperial de 1824, que previa:

Nos casos de rebellião, ou invasão de inimigos, pedindo a segurança do Estado, que se dispensem por tempo determinado algumas das formalidades, que garantem a liberdede ( sic) individual, poder-se-ha fazer por 
acto especial do Poder Legislativo. Não se achando porém a esse tempo reunida a Assembléa, e correndo a Patria perigo imminente, poderá o Governo exercer esta mesma providencia, como medida provisoria,e indispensavel, suspendendo-a immediatamente que cesse a necessidade urgente, que a motivou; devendo num, e outro caso remetter á Assembléa, logo que reunida fôr, uma relação motivada das prisões, e d'outras medidas de prevenção tomadas; e quaesquer Autoridades, que tiverem mandado proceder a ellas, serão responsaveis pelos abusos, que tiverem praticado a esse respeito.

Colocando esse dispositivo como antecessor, na tradição constitucional brasileira, do art. 80 da Constituição da República de 1891, Piza e Almeida fundamentou seu voto em uma ampla base de legislação imperial que aplicava o dispositivo do art. 179, XXXV, para demonstrar que, sob a Constituição Imperial, a detenção sem processo só era mantida durante a situação de rebelião ou invasão. Nas palavras do próprio, sobre as leis e decretos imperiais:

As leis e decretos citados, dando ao preceito constitucional sua verdadeira inteligência, terminantemente declaram que a faculdade, que tem o Governo, para mandar prender e conservar em prisão um cidadão sem ser sujeito a processo, é somente durante o tempo da suspensão de garantias, que deve necessariamente ser fixo e determinado (BRASIL, STF, HC 300, p. 3-4).

Assim, entendendo que "não se pode admitir que a Constituição Republicana seja interpretada e executada de modo menos liberal, e menos garantidor dos direitos e liberdades individuais, do que o foi a do império pelas leis e decretos citados" (BRASIL, STF, HC300, p.4), interpretou o art. 80 da Constituição de 1891 como impedindo a manutenção da detenção no estado de sítio. A conclusão desse voto divergente, portanto, foi a seguinte:

Durante o estado de sítio tem o Governo a faculdade de efetuar as prisões que a segurança do Estado exigir. Mas se levantado o estado de sítio, os cidadãos continuam presos ou desterrados, sem serem sujeitos a processo, havendo assim para eles uma suspensão de garantias por tempo indeterminado, contra a expressa disposição do art. 80 da Constituição, a lei os provê de remédio para resguardarem-se de semelhante violência, e esse remédio é o habeas corpus (BRASIL, STF, HC, 300, p.5).

Em 1893, o STF voltou a julgar Habeas Corpus de detidos em estado de sítio, mas desta vez com uma discussão razoavelmente diferente ao fundo. Uma vez colocado o entendimento do HC 300 de que as medidas não revestem caráter penal, mas que a detenção se estende após cessado o sítio até submeter o detido ao foro criminal competente, o tribunal foi chamado a decidir sobre detidos que alegavam não se enquadrarem na competência criminal da justiça militar. São três Habeas Corpus, impetrados por Ruy Barbosa em favor de diferentes pacientes, todos capturados a bordo do navio "Júpiter", embarcação de guerra rebelada contra o governo no episódio da Revolta da Armada. O primeiro destes a ser julgado foi o HC 406. Apresentados os 
pacientes ao STF, que eram em número de 48 no caso, concederam por maioria a soltura com um único argumento como fundamentação. $\mathrm{O}$ argumento dizia respeito à incompetência do Foro Militar para julgá-los diante dos fatos que eram imputados:

Vistos, expostos e discutidos os presentes autos de habeas corpus, em que são pacientes David Ben Obill e outros, resolve o Supremo Tribunal Federal conceder a referida ordem de soltura em favor dos detidos, visto ser ilegal a conservação da prisão em que se acham, desde que se verifica pelos autos e pelas informações prestadas, que os fatos que lhes são imputados, não constituem crimes que os sujeitem ao foro militar (BRASIL, STF, HC406, p.2).

Os votos divergentes também são igualmente sucintos e pouco argumentados. O ministro Bento Lisboa, cujo voto divergente se resume a uma frase, decidiu pela manutenção dos pacientes na prisão, visto que estes teriam cometido crimes inafiançáveis e sido detidos em flagrante delito, mas que deveriam ser conduzidos a um juízo competente, não militar, para serem processados por tais delitos. A outra divergência, do ministro Sobral, indica uma pequena ampliação nos fundamentos dessa postura, referindo ao fato do STF não reconhecer como vigorantes certos Códigos Penais da Marinha, promulgados em 1890 e 1891, e referindo a legalidade da prisão dos pacientes como sendo fundada no art. $1^{\circ}$, \$\$ $2^{\circ}$ e $5^{\circ}$ da Lei 631 de 1851 e art. 60, letra I, da Constituição de 1891. Diante da ausência de estruturas argumentativas mais elaboradas, essas referências à legislação, pelo ministro Sobral, são a única coisa que permite entrever o debate enfrentado pelo STF quando dessa decisão. $\mathrm{O}$ art. 60, letra I, da Constituição de 1891 fazia referência à competência dos Tribunais Federais para julgar crimes políticos. Com isso, entrevê-se que o que pretendia Sobral era a readequação da competência em relação aos pacientes, devendo-se retirá-la da Justiça Militar e passando à Justiça Federal, por se tratarem de crimes políticos. No entanto, as normas da Lei 631/1851 diziam respeito aos crimes de deserção, espionagem, sedução de militares para desertarem ou se levantarem contra o governo e atacar sentinelas. Mais especificamente, previam ritos distintos de processamento: quando estes crimes eram cometidos por militares, seriam processados nos termos daquela lei e de acordo com o Direito Penal Militar, ao passo que quando cometidos por paisanos, seriam processados nos termos da lei civil. O que se entrevê da leitura sistemática da legislação citada e da breve argumentação é que o voto de Sobral considerava a Lei 631/1850 como norma válida para o processamento dos militares envolvidos, mas que o cometimento dos mesmos crimes por civis configurava crime político, sendo julgado pela Justiça Federal, a partir da Constituição Republicana. Assim, reproduz-se nessa decisão a lógica do HC 300 de que a detenção no estado de sítio é pré-penal, quer dizer, é prévia a um processo penal, mas sem o caráter de pena. Mais ainda, a decisão da maioria é de que, no caso de não serem levados os detidos ao foro competente, a detenção torna-se ilegal e cessa após o Estado de Sítio cessar. De outro lado, também se observa o reconhecimento do aspecto de crime político aos fatos delituosos cometidos por civis e que resultem na detenção 
excepcional.

No Habeas Corpus 410, julgado pelo STF na semana seguinte ao julgamento do HC 406, tratou-se de um imediato do navio Júpiter, que fora detido e mantido incomunicável, e que por isso foi defendido em Habeas Corpus em separado, após o julgamento dos demais, mas que estava inserido, no tocante aos fatos e a características subjetivas, no mesmo grupo do Habeas anterior. Mesmo assim, a corte não se limitou a estender ao imediato a decisão do HC 300, mas o fez com uma fundamentação aumentada, mas ainda consideravelmente breve, para conceder a soltura. Sobre essa fundamentação, é importante destacar o seguinte trecho:

Que incumbe aos Tribunais de Justiça verificar a validade das normas que têm de aplicar aos casos ocorrentes e negar efeitos jurídicos àquelas que forem incompatíveis com a Constituição, por ser esta a lei suprema e fundamental do país;

Que este dever não só decorre da índole e natureza do Poder Judiciário, cuja missão cifra-se em declarar o direito vigente, aplicável aos casos ocorrentes regularmente sujeitos à sua decisão, se não também é reconhecido no art. 60, letra "a", da Constituição que inclui na competência da Justiça Federal o processo e julgamento das causas em que alguma das partes fundar a ação ou a defesa em disposição Constitucional (BRASIL, STF, HC 410, p.2);

Nesse trecho, o STF reconhece a existência do controle difuso de constitucionalidade no sistema jurídico brasileiro. Tal questão, referente ao controle de constitucionalidade no Brasil, sob a Constituição de 1891, voltaria a ser detalhadamente discutida em outro momento, nas ações dos reformados pelos atos do Marechal Floriano Peixoto no contexto da Revolta da Armada, que foi proposta por Ruy Barbosa (BARBOSA, 2010, p. 11 14). Mas já nesse Habeas Corpus, o STF reconhecia tal mecanismo e colocava-o nas bases de sua decisão. É uma das primeiras menções ao controle de constitucionalidade na jurisprudência nacional. Que tenha ocorrido em uma decisão sobre o Estado de Sítio pode representar um indicativo da importância de um controle de constitucionalidade adequado nas situações limite da Constituição, especialmente em relação ao estado de exceção. Assim, é justamente no ponto em que o quadro da Constituição está em risco de romper-se que o controle de constitucionalidade demonstra sua essencialidade.

Além disso, na decisão no caso, a Corte resolveu um ponto essencial ao controle de constitucionalidade, que é a distinção entre a não aplicação e a revogação, explicando que a consequência da inconstitucionalidade é a não aplicação, e que esta não se confunde com a revogação da norma (a qual compete apenas ao legislador, no sistema de controle de constitucionalidade difuso do Brasil à época).

Outro ponto diz respeito às competências na exceção. Logo após a proclamação da República, dentro do contexto do governo ditatorial e provisório, foi concedida ao Ministério da Marinha (órgão do Executivo, portanto) a competência de reformar o Código da Armada. No entanto, o Ministério da Marinha apenas fez uso 
dessa competência após a Constituição de 1891 entrar em vigor, ou seja, já fora do período de exceção do governo provisório. O STF entendeu, então, que este uso da competência era inconstitucional, porque a Constituição marcava um retorno à normalidade e que com isso caducava a competência excepcional, pois a Constituição reservara ao Legislativo o poder de legislar. Assim, temos aqui a inconstitucionalidade de uma medida de exceção tomada fora do prazo dado sendo declarada pelo STF, a partir da qual observamos um controle judicial sobre o quadro normativo de exceção, a partir do retorno à normalidade constitucional.

A consequência disso, no caso, foi que a competência para processar o detido seria determinada a partir do Código Penal e da legislação militar do período do Império. Com isso, a Lei 631/1851, citada pelo ministro Bento Lisboa no HC 406, foi invocada no HC 410, justamente para comprovar que o crime de sedução à deserção ou ao levante contra o governo era de competência da Justiça comum, quando cometido por civis. Com isso, ausente a jurisdição militar, a decisão entendia que a prisão militar sendo incompetente o foro militar configurava constrangimento ilegal, suficiente para deferir o Habeas Corpus. O único voto divergente nesta decisão, do ministro Ferreira de Resende, negava a soltura alegando que não haviam sido apresentados o paciente nem as informações necessárias, motivo pelo qual se considerava inabilitado para julgar a causa, sem desenvolver quanto ao mérito.

Essa necessidade de encaminhar os detidos ao juízo correto, sob pena de ser concedida a soltura com o fim da detenção, pode ser entendida mais claramente na decisão do Habeas Corpus 415, também impetrado por Ruy Barbosa, mas que tinha por pacientes dois oficiais reformados do exército e um senador, Eduardo Wandenkolk, o qual era também oficial da marinha antes do ingressar à carreira política. São duas as questões trazidas no Habeas Corpus: por um lado a demora além do legalmente estipulado para a formação da culpa do senador Wandenkolk e a imunidade parlamentar deste, por outro a tese de que os militares reformados seriam isentos do foro militar pela reforma e que a indivisibilidade da ação implicava que todos os réus fossem julgados perante o mesmo foro, no caso, perante a justiça civil, competente para os paisanos presos no navio Júpiter. Quanto ao senador Wandenkolk, basta referir que este não fora julgado porque a Câmara não havia julgado a procedência da ação, necessária para se afastar a imunidade parlamentar e seguir o processo. O STF não se prolongou sobre os efeitos de manter a detenção enquanto a Câmara não decidia sobre a imunidade, o que leva a um problema real da detenção sem caráter penal no Estado de Sítio, na medida em que essa detenção coloca as próprias imunidades e garantias processuais que cercavam o direito fundamental à liberdade de locomoção contra o direito fundamental, na medida em que estes mecanismos, criados para evitar a prisão até que se tenha certeza da legalidade dessa, passam a impedir a liberdade até que se tenha certeza da ilegalidade da prisão.

Quanto aos militares reformados, a decisão apresenta um grande conjunto de normas anteriores e de precedentes, formando uma demonstração extremante completa da jurisprudência da época, para demonstrar 
que os oficiais reformados eram considerados, sistematicamente, como militares (BRASIL, STF, HC415, p.2-3). Por fim, a distinção entre militares e paisanos, para as consequências das detenções naquele estado de sítio, em que todos os detidos foram encaminhados a prisões militares, é de tal importância que ocupa a maior parte da fundamentação da decisão do HC 415 o entendimento do STF de que o direito brasileiro à época não acolhia o princípio da indivisibilidade da ação pública, mesmo reconhecendo este princípio como recomendável. O STF reconheceu que, diante da Lei 631/1851, não havia espaço para se interpretar a existência de indivisibilidade, pois a própria lei previa foros distintos para o mesmo crime, em sendo cometido por militar ou por paisano (BRASIL, STF, HC415, p.3-4). Com isso, negaram a soltura dos pacientes, pois de acordo com o artigo 47 do decreto 848/1890, editado pelo governo provisório e recepcionado, no entender anterior do STF, pela Constituição de 1891, o Supremo Tribunal Federal não podia conceder habeas corpus quando verificada o "regime militar" para o processamento do crime. $^{6}$

Assim foi a decisão do STF por maioria, mas essa decisão suscitou várias divergências internas no Tribunal. $\mathrm{O}$ voto divergente do ministro José Higyno, pela concessão da ordem de soltura, centra-se no argumento de que o caráter subjetivo de militar só perdura enquanto perdurar o serviço militar propriamente dito (BRASIL, STF, HC415, p.5-8). É interessante observar este papel da justiça militar brasileira nos primeiros momentos da regulação do estado de exceção como estado de sítio, nas palavras do voto divergente do ministro José Higyno no HC 415:

Entre nós o juízo militar não é somente especial, conserva ainda o caráter de justiça de exceção, pois assim se chama aquela que é administrada por juízes comissários nomeados ad hoc para conhecerem de casos concretos. Os nossos conselhos de investigação e de guerra não são tribunais permanentes, mas verdadeiras juntas militares de nomeação do governo (BRASIL, STF, HC415, p.7).

Assim, se mostra aqui um aspecto do estado de sítio no sistema jurídico brasileiro da Constituição de 1891. Com a recepção de atos de um governo ditatorial provisório (por si só, um estado de exceção, não regulado, parte do interregno entre as Constituições de 1824 e 1891), acabava-se criando uma situação em que uma classe de atingidos pelos atos de estado de sítio era mantido na detenção excepcional até o seu julgamento também por um tribunal excepcional. Assim, para os militares detidos no estado de sítio, acumulavam-se excepcionalidades, colocando a restrição de seus direitos fundamentais de liberdade em uma zona grandemente afastada da normalidade do quadro jurídico constitucional previsto para os demais. Isso como consequência da combinação entre a sistemática do estado de sítio conforme vinha sendo interpretada pelo STF com o art. 47 do Decreto

\footnotetext{
${ }^{6}$ Dizia o seguinte, o art. 47 do Decreto 848/1890: "O Supremo Tribunal Federal e os juizes de secção farão, dentro dos limites de sua jurisdicção respectiva, passar de prompto a ordem de habeas-corpus solicitada, nos casos em que a lei o permitta, seja qual for a autoridade que haja decretado o constrangimento ou ameaça de o fazer, exceptuada, todavia, a autoridade militar, nos casos de
} 
$848 / 1890$.

Tal recepção do decreto 848/1890 é questionada no voto de Macedo Soares, que nega a soltura, mas por fundamentos diversos. Como a Constituição de 1890 previa o uso do Habeas Corpus como sendo uma garantia do indivíduo, não havendo motivos para se crer que a Constituição excluiria os militares desta garantia, de modo que estava revogado implicitamente a exceção do Decreto 948/1890. Considerava, no entanto, que os três pacientes daquele Habeas Corpus eram sujeitos ao regime militar, que haviam cometidos crimes militares flagrantes e que a demora na formação de culpa se justificava pela necessidade de juízo do Congresso com relação a prisão do senador Wanderkolk, não havendo a ilegalidade na detenção, segundo esse entendimento.

Com isso, ao longo de três Habeas Corpus, o STF formulou o início de sua jurisprudência sobre o estado de sítio, em resposta ao primeiro uso desse instituto, na Revolta da Armada, logo nos primeiros anos da República. Entretanto, ainda na mesma década, o STF viria a ser provocado tomar novas decisões sobre o tema, por uma nova declaração de estado de sítio, fruto das instabilidades políticas da República nascente.

\section{CESSAÇÃO DA EXCEÇÃO: A DURAÇÃO DAS SANÇÕES DO ESTADO DE SÍTIO, NAS DECISÕES DO STF DE 1898, APÓS A TENTATIVA DE ASSASSINATO CONTRA O PRESIDENTE PRUDENTE DE MORAIS}

Em 1897, se declara mais uma vez um estado de sítio, no Distrito Federal e na comarca de Niterói, por meio do Decreto do Poder Legislativo 456, de 12 de novembro de 1897, e que seria prorrogado até 23 de fevereiro de 1898, pelos Decretos 2737 e 2810, sucessivamente. O motivo era a tentativa de assassinato contra o presidente Prudente de Morais, resultando em um estado de sítio que se estendeu por quatro meses, ao longo dos quais foram realizadas várias detenções de suspeitos ou de opositores políticos ao governo. O decreto do Poder Legislativo apenas faz menção à decretação do estado de sítio no Distrito Federal e na comarca de Niterói, no estado do Rio de Janeiro, sem citar motivações ou especificar medidas. Uma dessas medidas foi determinar a detenção de alguns opositores, suspeitos de conspirar contra o governo, e enviá-los, como desterrados, para a ilha de Fernando de Noronha. Uma vez terminado o estado de sítio, em 23 de fevereiro de 1898, seguiam ali detidos vários sujeitos, o que motivou a impetração de dois Habeas Corpus, cuja decisão centrou-se ao redor da duração dos efeitos do estado de sítio.

No Habeas Corpus 1063, impetrado por Ruy Barbosa em defesa de uma série de pacientes, sendo três deles parlamentares, um oficial militar, e dois civis, se discute os limites temporais da medida de exceção do desterro, principalmente, além da pretensão de Ruy Barbosa em ver reconhecido:

jurisdicção restricta e quando o constrangimento ou ameaça for exercido contra individuos da mesma classe ou de classe vol.10, no. 02, Rio de Janeiro, 2017.pp.1090-1124 
[...] que a jurisprudência adotada pelo Supremo Tribunal, quanto às conseqüências dos atos praticados em estado de sítio, não pode continuar a vigorar; que o acórdão de 27 de abril de 1892 que a consagrou, toldando a transparência do direito, foi um erro judiciário, e que assim deveria ser concedida aos pacientes a soltura impetrada (BRASIL, STF, HC1063, p.2).

No entanto, a decisão não atendeu às pretensões de Ruy Barbosa. O STF seguiu entendendo pela "Doutrina da Questão Política", que afirmava que compete ao Congresso examinar as decisões do Executivo tomadas no estado de sítio, e que era assentada desde a decisão do Habeas Corpus 300, que inaugurara a questão do estado de sítio perante o STF. No acórdão do HC 1063, o STF expande ainda mais a fundamentação desta doutrina. Primeiramente, situaram a interpretação a partir do disposto do art. 80, $\$ 3^{\circ}$ da Constituição de 1891 , que dizia que "Compete privativamente ao Congresso aprovar ou suspender o sítio que houver sido declarado pelo Executivo ou seus agentes responsáveis”. A partir daí, interpretam que não cabe ao Judiciário apreciar os atos de sítio, antes do juízo político do Congresso, sob o argumento de que seria "violência ao sentido natural dessas palavras" uma interpretação distinta. Assim, parte de uma interpretação literal da Constituição, ou melhor dizendo, que depende do que o ministro do STF via como literalmente explicitado no texto. Mais, segundo o STF, por ser "impossível separar" os direitos individuais da questão política, nem a violação desses habilitava o Poder Judiciário a intervir. Nisso, o STF só reiterava a sua doutrina da questão política. O que esse acórdão traz de novo ao sistema jurídico brasileiro são as consequências dessa doutrina para a duração da restrição dos direitos individuais por medidas de exceção:

Assim, firmado este princípio, segue-se o seu consectário de que os efeitos do estado de sítio não se extinguem, com relação às pessoas que por ele foram atingidas, se não depois que o Congresso conhecer dos atos praticados pelo chefe do Poder Executivo (BRASIL, STF, HC1063, p.2).

Com isso, o STF delineia uma concepção do estado de sítio em que, pelo entendimento em favor de uma natureza política deste, permite que a restrição do direito individual, mesmo após o retorno à normalidade constitucional, se perpetue até um juízo político. Essa continuidade dos efeitos após a cessação do estado de sítio, segundo a decisão do STF, seria amparada na legislação de países estrangeiros, citando como direito comparado a continuidade de submissão dos processos-crimes a foros militares, mesmo após findo estado de sítio, na França (Referindo-se ao texto normativo "Levantado o estado de sítio, os tribunais militares continuarão a conhecer dos crimes e delitos, cujos processos thes tenham sido conferidos", presente nas leis de agosto de $1849^{8}$ e abril de

differente, mas sujeitos a regimento militar".

${ }^{7}$ BRASIL. Supremo Tribunal Federal. Habeas Corpus n. 1063. Paciente: João Cordeiro e outros. Relator: Ministro Bernardino Ferreira. Rio de Janeiro, 03 de março de 1898 e 26 de março de 1898. p.2.

${ }^{8}$ É essencial aqui referir que a Corte de Cassação francesa, à época, declarou contrária à Constituição o julgamento de paisanos por foros militares, no contexto da primeira declaração do estado de sitio motivada por rebelião e não por guerra, e que a lei de 1849 foi uma resposta do governo a essa limitação colocada pela jurisdição constitucional, a qual o governo considerava "perigosa": "En este estado de la lejislacion, se produjo la célebre decisión de la Corte de Casación en 1832 que declaraba 
$1878^{9}$ ) e no Equador (Constituição do Equador de 1897), ${ }^{10}$ e na proibição do Judiciário de conceder Habeas Corpus à cidadão envolvido em rebelião nos Estados Unidos (o STF refere a uma "lei de 5 de fevereiro de $\left.1867^{\prime \prime}\right)^{11}$

Mais do que essas alusões ao direito comparado, o que origina a posição do STF é uma preocupação com a "defesa social", no sentido de que cessadas as medidas de exceção, poderia retornar à emergência que conduziu ao sítio. Isso é evidente no seguinte trecho da decisão: "E depois, seria contrário à índole do estado de sítio, medida mais de caráter preventivo do que repressivo, que fosse lícito por meio do habeas corpus anular os atos que praticou o Presidente da República, em bem do interesse e defesa social" (BRASIL, STF, HC1063, p.3). Tal formulação, coerente com a postura da corte, desenvolve-se, como se pode notar, ao redor do caráter preventivo das medidas de exceção, já assentado em decisões anteriores. Por outro lado, essa formulação deixa ao tribunal um problema novo: se ainda eram necessárias as medidas de sítio para a defesa social, como a decisão pressupões, por que não se teria prorrogado o estado de sítio? O acórdão responde diretamente essa pergunta, da seguinte maneira: "Ora, não precisa grande esforço de raciocínio para desde logo se condenar um sistema que exige das liberdades públicas tão grande sacrifício, e que impõe às instituições democráticas o seu descrédito com a permanência do estado de sítio" (BRASIL, STF, HC1063, p.3). Ainda assim, mesmo negando a ordem, e mantendo as medidas excepcionais para além da duração do sítio, deixando o direito individual na dependência de um juízo político do Congresso, o STF insiste ainda em reafirmar seu papel de corte constitucional, limitadora

contraria á la Constitución el someter, bajo el estado de sitio, á los tribunales militares los individuos que no participaban de este carácter, pues les sacaba de sus jueces naturales. El gobierno creyó peligrosa esta jurisprudencia, y aunque presentó un proyecto á las Cámaras, recien en 1849 se dictó ley á su respecto á consecuencia de un proyecto presentado por Dufaure. La ley de 9 de Agosto de 1849, si bien no aceptó las conclusiones de la decisión de la Corte de Casación de 1832, hizo posible su existencia" (ALCORTA, 1881, p. 173). Na prática, essa lei, que marca o surgimento do estado de sítio chamado de fictício, isto é, onde não há um cerco literal, mas uma situação de emergência política, havia sido uma maneira do governo francês escapar às restrições colocadas pela jurisdição constitucional para manter o estado de sítio dentro do quadro da constituição.

${ }^{9}$ Esta lei reproduzia a regulação do estado de sítio de 1849, com algumas alterações: "La ley de 1878 mantiene espresamente las disposiciones de la de 1849 en sus artículos $4^{\circ}$ y $5^{\circ}$, y en todo lo demás que no lo sea contrario; pero la modifica en cuanto á los casos en que puede ser declarado el estado de sitio, y en cuanto á la autoridad á quien compete" (ALCORTA, 1881, p. 174).

${ }^{10}$ Este dispositivo legal não é citado diretamente pelo STF, uma vez que a corte faz referência a ele por meio da alusão ao escrito na obra "Las garantias constitucionales" de Alcorta, a qual transcreve-se aqui: "El Ecuador reformó su Constitución en 1869. Según el inciso 12 del artículo 60 corresponde al Poder Ejecutivo: «Declarar en estado de sitio con acuerdo del Congreso, ó en su receso del Consejo de Estado, integra ó parcialmente, el territorio de la República por tiempo determinado, en caso de suceder ó amenazar ataque esterior ó conmoción interior; y decretar su cesación. Si reunido el Congreso durare todavía el estado de sitio, corresponde al Poder Legislativo decretar la cesación ó continuación». Según el artículo 61: «Declarado el estado de sitio corresponde al Gobierno: $1^{\circ}$ Ordenar el allanamiento y registro del domicilio de personas sospechosas; [...] $7^{\circ}$ Disponer se juzguen militarmente como en campaña, y coa las penas de las ordenanzas militares, á los autores, cómplices y auxiliares de los crímenes de invasión esterior, aún cuando haya cesado el estado de sitio. Si la sentencia fuere condenatoria, no se llevará á ejecución antes de ponerla en conocimiento del Poder Ejecutivo para que haga ó no uso de la atribución que le confiere el $\$ 4$ del artículo 60 de la Constitución »" (ALCORTA, 1881, p. 192-193). Grifos adicionados no presente trabalho.

${ }^{11}$ Esta lei também é constante de ALCORTA, Amancio. Las Garantias Constitucionales. $1^{\text {a }}$ ed. Buenos Aires: Libraurue Générale, 1881. p.50 e 72. O fato de que toda a legislação estrangeira citada nessa decisão se encontra na obra de Alcorta, parece indicar que esta obra teve algum nível de influência no pensamento do STF estado de sítio ou que, alternativamente, esta obra apresenta uma visão algo coincidente sobre o Direito da época. 
dos poderes do Executivo, no final do voto vencedor do acórdão:

Assim, pois, se as medidas discricionárias do Presidente da República, durante o estado de sítio, têm os seus limites no Pacto Fundamental, que da mesma sorte indica, nesta grave emergência da vida social, qual o procedimento que compete ao Congresso, é manifesto que a inobservância de tais preceitos abrirá espaço à intervenção do Poder Judiciário (BRASIL, STF, HC1063, p.3).

Desta maneira, na mesma decisão em que opta por não limitar a duração as medidas excepcionais, fundamentando com base no aspecto político das decisões sobre a exceção, o STF ainda assim reconhece um quadro jurídico dentro do qual esse juízo político decide. Apenas quando a medida se apresente fora dos limites desse quadro constitucional é que o STF se presta a intervir com a desaplicação da medida excessiva para o caso concreto. Isso implica, por outro lado, que se reconhece a detenção indeterminada de cidadãos como estando dentro do quadro constitucional do Direito Constitucional brasileiro à época, o que implica uma possibilidade de restrição grave de direitos fundamentais sendo autorizada pelo STF.

O voto vencido no HC 1036, do ministro Manoel Murtinho, está centrado ao redor de um argumento formal e de um material. O formal é, essencialmente, que se o Tribunal expediu ordem para o comparecimento dos pacientes e requisitou informações, ele reconhecera implicitamente sua competência para o Habeas Corpus, ao entrar na matéria ${ }^{12}$. Destacou, inclusive, que esse havia sido o procedimento no HC 300 . Assim, o tribunal não podia negar a ordem se considerando incompetente, pois já havia superado essa questão.

Mais importante é o argumento material deste voto vencido. Em primeiro lugar, apela à coerência da jurisprudência da corte, lembrando que em voto anterior do ministro Piza e Almeida, que fora relator do voto vencedor, este reconhecera a cessação dos efeitos junto com o fim do estado de sítio. ${ }^{13}$ Em sequência, passa a argumentar que o juízo político do Congresso não interfere no espaço de decisão do Poder Judiciário, no sentido de que apenas a duração do estado de sítio afasta a competência do Judiciário, e que uma vez encerrado o estado de sítio, o Judiciário pode conhecer e decidir sobre as medidas coercitivas praticadas contra os cidadãos, mesmo

\footnotetext{
12 "A concessão, portanto, do habeas corpus, mesmo no que se chama a sua primeira fase, pressupõe que a competência do Tribunal para prover com esse remédio judiciário é um ponto líqüido, incontroverso e definitivamente decidido" (BRASIL, STF, HC,1063 p.4).

13 "Convém ainda consignar aqui, por pertencer ao histórico da primeira fase deste habeas corpus, que, tratando-se na mesma sessão de um pedido idêntico, visto versar sobre o desterro político de um dos pacientes, o respectivo relator, o Sr. Ministro Piza e Almeida, aduziu, como um dos fundamentos pelos quais opinava pela concessão da ordem de habeas corpus impetrada, a doutrina de que, cessado o estado de sítio, devem cessar todas as medidas repressivas autorizadas na vigência dele pela Constituição -, e esse fundamento foi adotado, assim na discussão como na votação, uma vez que nenhum julgador contestou-o e nem pôs-the qualquer restrição, tanto que a ordem foi concedida unanimemente, ampliando-se esta decisão à petição de que rezam estes autos por ser perfeitamente idêntica a matéria. Assim, pois, o Tribunal não limitou-se então a afirmar sua competência; foi além; deixando entrever, senão manifestando previamente qual seria sua decisão definitiva, visto como, quem admite o princípio de que com o estado de sítio devem desaparecer as medidas de repressão constitucionalmente tomadas durante ele, tem, ipso facto, reconhecido que o desterro político, mantido após a expiração daquele regimen excepcional, tornouse um ato inconstitucional, e, portanto, causa a quem o sofre um constrangimento ilegal, para o qual o remédio judiciário é a plena concessão do habeas corpus" (BRASIL, STF, HC1063, p.5).
} 
que originadas no estado de sítio:

Cessado, entretanto, o sítio, e restabelecida com as garantias constitucionais a plenitude das funções judiciárias, se a justiça federal, legitimamente provocada, depara com uma prisão, com um desterro ordenado pelo Governo, como tais medidas somente são permitidas pela lei fundamental durante o estado de sítio, não pode a mesma justiça deixar de proclamá-las inconstitucionais na atualidade (embora fossem justificáveis quando se decretaram, pois disso julgará o Congresso), e conseqüentemente, ocasionarem aos que as sofrem coação ilegal, socorrendo os pacientes com a tutelar providência do habeas corpus (BRASIL, STF, HC1063, p.6).

Outro argumento a ser notado nesse voto divergente é que o Judiciário não pode se imiscuir no papel do Executivo de preservar a ordem pública, de modo que quando o Executivo não prorroga o estado de sítio, não poderia o Judiciário prorrogá-lo para indivíduos específicos, uma vez que uma das funções da jurisdição seria salvaguardar o direito individual (BRASIL, STF, HC1063, p.6). Com isso, configurava-se nesse acórdão duas linhas de entendimento: uma conferia quadro muito amplo às medidas de exceção, ao reconhecê-las constitucionais mesmo após cessado o estado de sítio, desde que decretadas em meio a este. Outra que limitava as medidas de exceção em duração ao período do estado de sítio, após o que a jurisdição era competente para intervir e fazer cessar essas medidas, cuja permanência passa a ser inconstitucional.

Outro Habeas Corpus questionou a continuidade das medidas de exceção em favor de vários dos desterrados em Fernando de Noronha. Este é o primeiro Habeas em que o STF é levado a decidir sobre sítio sem ter Ruy Barbosa como impetrante. A decisão desse HC 1073, tomada apenas um mês após o HC 1063, é um ponto essencial na história da jurisprudência constitucional sobre o estado de sítio, na medida em marca uma virada na postura do STF, em que a posição majoritária na corte passa a ser em favor da limitação temporal das medidas do estado de sítio, bem como do controle da adequação das medidas de sítio à constituição e pelo Poder Judiciário.

Três dos pacientes deste Habeas Corpus eram parlamentares, o que lhes implicou um tratamento distinto dos demais pacientes, em razão das imunidades. Como pode ver-se, desde a detenção do senador Wandenkolk, em meio à revolta da armada, até a detenção destes pacientes (um senador e dois deputados), entre outros parlamentares detidos em meio ao estado de sítio, vinha se convertendo em prática recorrente, nesses primeiros anos da República Velha, a detenção ou desterro de parlamentares pelo governo, o qual aproveitava a suspensão de garantias pelo estado de sítio para afetar a imunidade parlamentar da oposição no Congresso. Diante da reiteração desse tipo de prática, que obviamente provocava um certo desequilíbrio no caráter democrático da representação, o STF parece ter se decidido a assumir para a instituição o papel de controlar as arbitrariedades do Executivo em meio ao estado de sítio. Por isso, o STF acabou reconhecendo, nessa decisão, uma das primeiras limitações à extensão do estado de sítio na tradição brasileira, ao excluir a imunidade 
parlamentar do rol das garantias que podiam ser suspensas pelo estado de sítio. ${ }^{14}$

A decisão não se limita a restringir o quadro das medidas de exceção quanto à especificação de garantias, pois reconheceu a limitação temporal da duração das medidas tomadas no estado de sítio. $\mathrm{O}$ argumento era justamente um que já se encontrava no voto divergente do HC 1063, baseado no raciocínio de que a nãoprorrogação do estado de sítio significava o fim da emergência. Sendo que o próprio caráter emergencial é que justificava a detenção, esta não pode subsistir após a cessação do sítio, como decorrência lógica. ${ }^{15}$

Outro dos argumentos para a limitação temporal das medidas de exceção, nessa mudança na postura da corte, é a própria limitação temporal exigida das penas regulares, impostas pelo Judiciário, que a corte entende que deve ser estendida às medidas de repressão impostas pelo Executivo. ${ }^{16} \mathrm{~A}$ estrutura lógica colocada é que se um processo judiciário com todas as garantias não pode impor penas ilimitadas, uma decisão arbitrária sem quaisquer garantias processuais teria ainda menos legitimidade para impor tais penalidades. A corte inclusive faz referência à obra "O Estado de Sítio", de Ruy Barbosa, para corroborar este argumento. ${ }^{17}$

Outro argumento do tribunal se funda em uma interpretação histórica, apresentando a prática legislativa e a interpretação constitucional no período do Império, para concluir que tal corpo jurídico já continha limitações

\footnotetext{
14 "Considerando que a imunidade, inerente à função de legislar, importa essencialmente à autonomia e independência do Poder Legislativo, de sorte que não pode estar incluída entre as garantias constitucionais que o estado de sítio suspende, nos termos do art. 80 da Constituição, pois, de outro modo, se ao Poder Executivo fosse lícito arredar de suas cadeiras deputados e senadores, ficaria à mercê do seu arbítrio, e, por isso mesmo, anulada a independência desse outro poder político, órgão, como ele, da soberania nacional (Const., art. 15) e o estado de sítio, cujo fim é defender a autoridade e livre funcionamento dos poderes constituídos, converter-se-ia em meio de opressão senão de destruição de um deles (sentença de 15 de dezembro de 1893, da Suprema Corte Argentina, no recurso de habeas corpus do senador Alem)" (BRASIL, STF, HC1073, p.2).

15 "Absurdo seria subsistirem as medidas repressivas, somente autorizadas pelas exigências da segurança da República, que determinam a declaração do sítio, quando tais exigências têm cessado pelo desaparecimento da agressão estrangeira, ou da comoção intestina, que as produziram, pois seria a sobrevivência de um efeito já sem causa, e certo é, na hipótese ocorrente, que a comoção interna, motivo do decreto legislativo de 12 de novembro do ano passado e dos decretos do Poder Executivo que o prorrogaram, desde muito terminou, pois, desde 23 de fevereiro cessou o estado de sítio que a atestava, e, pois, com ele, não podiam deixar de cessar as medidas de exceção que só ela legitimava” (BRASIL, STF, HC1073, p.2).

16 "Outro e não menor absurdo seria que pudessem durar indefinidamente transitórias medidas de repressão deixadas ao arbítrio do Poder Executivo, quando nas próprias penas impostas pelo Judiciário, com todas as formas tutelares do processo, é requisito substancial a determinação do tempo que hão de durar (Ruy Barbosa, O estado de sítio, pág. 178)" (BRASIL, STF, HC1073, p.2).

${ }^{17}$ A decisão está se referindo ao seguinte trecho da obra de Ruy Barbosa citada, em que este critica a decisão do próprio STF no acórdão do HC300: "Si a pena por tempo indeterminado é intoleravel; si a determinação do tempo é requisito substancial da pena em todas as legislações, como admittir para os actos do arbitrio, o que não se admitte para as sentenças da justiça? Como admittir prisão por tempo indeterminado, ao talante do executivo, quando a não admittimos aos tribunaes? Mas é precisamente o que se teria de aceitar, a prevalecer a theoria inaudita do acórdão" (BARBOSA, 1892, p. 178). Note-se que o HC 1073 é o primeiro, dentre toda uma série de habeas corpus questionando perante o STF as medidas do estado de sítio, que não foi impetrado pelo próprio Ruy Barbosa. A produção acadêmica de Ruy Barbosa jamais fora citada nas decisões dos writs por ele impetrados. Também chama a atenção o papel da autoridade acadêmica da doutrina na formação do entendimento das cortes, uma vez que a mesma pessoa pode influenciar em uma mudança de posicionamento da corte de maneira muito mais efetiva como acadêmico, ao passo que, em sua atuação advocatícia, foi arduamente resistido nos posicionamentos que postulava. Essa obra de Ruy Barbosa, aliás, foi motivada pela própria experiência do jurista ao questionar o estado de sítio perante o STF, visto se tratar de uma coletânea de artigos escritos pelo autor em resposta às decisões do STF sobre o estado de sítio, criticando-as minuciosamente.
} 
à duração de medidas excepcionais fundadas na suspensão de garantias. Esse argumento não é novo, como o próprio acórdão referencia, pois é uma reprodução da argumentação do voto divergente do ministro Piza e Almeida na decisão do HC300 (BRASIL, STF, HC1073, p.3).

A retomada dos argumentos do voto divergente do ministro Piza e Almeida não se limita aí. $\mathrm{O}$ acórdão do HC 1073 também reproduz, ainda que sem referenciar, aquela interpretação a contrario sensu do Regimento Interno do STF, elaborada por Piza e Almeida para fundamentar a competência do tribunal para conhecer do habeas corpus sobre medida tomada no estado de sítio, assim que cesse este estado. No entanto, à interpretação a contrario sensu do regimento interno, foi adicionado um argumento sobre a distinção entre o juízo judicial e o juízo político do Congresso, no sentido de que um não obsta o outro, por se tratarem de questões diferentes (responsabilidade dos agentes do Executivo no juízo político, direitos e garantias individuais no juízo jurídico). ${ }^{18}$ Justamente, o tribunal desenvolve o entendimento de que o Congresso não pode fazer o juízo sobre os direitos dos detidos, o que implica esta separação entre juízo político e jurídico, e a independência entre eles. ${ }^{19}$

Em voto concordante, mas por fundamentos diversos, o ministro Macedo Soares aventou nesta decisão, para afastar uma possível acusação de incoerência por votar de maneira distinta no HC 300 e nesse HC 1073, uma argumentação curiosa. Ao longo dessa fundamentação, ele desenha um controle material de constitucionalidade da própria declaração do estado de sítio. Argumentando que havia votado a favor da continuidade das detenções no sítio de 1892 porque este tinha sido declarado de modo "perfeito", ao passo que votava contra a continuidade nas detenções no sítio de 1897, porque este estado de sítio:

[... ]é inconstitucional, é irracional, é falso na afirmação dos fatos, é despótico: e assim, não consulta o bem da Nação; ao contrário, violando a Constituição Federal, cava a ruína da República, implantando nela uma ditadura, que nem sequer tem a justificativa de ser

\footnotetext{
18 "O próprio Regimento Interno do Tribunal, no art. $65, \$ 3^{\circ}$, consagra esta doutrina, quando dispõe que o Tribunal se declarará incompetente para conceder a ordem de habeas corpus se se tratar de medida de repressão autorizada pelo art. 80 da Constituição, enquanto perdurar o estado de sítio;

Considerando mais que a esta interpretação do ponto constitucional não obsta a atribuição privativamente conferida ao Congresso Nacional, no art. 34, n. 21, da Constituição, para aprovar ou suspender o sítio que houver sido declarado pelo Poder Executivo, na ausência dele, e, no art. $80, \mathbb{S} 3^{\circ}$, para conhecer das medidas de exceção que houverem sido tomadas e que o Presidente da República lhe relatará, pois tal atribuição, para o único efeito de decretar-se, ou não, a responsabilidade dos agentes do Poder Executivo (lei de 8 de janeiro de 1892, art. 33), não exclui a competência do Judiciário senão para esse julgamento político, que não para o diverso efeito de amparar e restabelecer os direitos individuais que tais medidas hajam violado, quando delas venha regularmente a conhecer por via de pedido de habeas corpus;

Considerando que a ação judiciária, suspensa durante o estado de sítio para o habeas corpus, em relação aos atingidos pelos efeitos do mesmo sítio, como suspensas estão, ou podem estar, todas as garantias individuais, com elas se restabelece e revigora pela cessação daquele estado excepcional e transitório” (BRASIL, STF, HC1073, p.3).

19 "Considerando que, se a garantia do habeas corpus houvesse de ficar suspensa enquanto o estado de sítio não passasse pelo julgamento político do Congresso, e de tal julgamento ficasse dependendo o restabelecimento do direito individual ofendido pelas medidas de repressão empregadas pelo Governo no decurso daquele período de suspensão de garantias, indefesa ficaria por indeterminado tempo a própria liberdade individual e mutilada a mais nobre função tutelar do Poder Judiciário, além de que se abriria abundante fonte de conflitos entre ele e o Congresso Nacional, vindo a ser este, em última análise, quem julgaria os indivíduos atingidos pela repressão política do sítio, e os julgaria sem forma de processo e em foro privilegiado não conhecido pela Constituição e pelas lei" (BRASIL, STF, HC1073, p.3-4).
} 
inteligente e patriótica (BRASIL, STF, HC1073, p.4).

Assim, o ministro Macedo Soares faz um juízo quando a conveniência da declaração do estado de sítio para a "salvação da pátria", para considerar que o sítio que o tribunal entender que não atenda esse fim é nulo, não produzindo efeitos. ${ }^{20}$ No entanto, não discorre de maneira mais detalhada sobre como o tribunal poderia fazer tal juízo material de conveniência ou adequação, o que torna essa construção pouco firme, diante da existência do juízo político do Congresso, o qual dizia respeito exatamente sobre a conveniência das decisões no estado de sítio. A única indicação é que o ministro considera o regicídio (no caso, tentativa de assassinato contra o Presidente) como motivo insuficiente para declarar o estado de sítio com base em casos de outros países que não fizeram tal declaração após casos de regicídio. ${ }^{21}$

O restante da fundamentação de Macedo Soares é para afastar a característica de "arestos", atribuída pelo governo à jurisprudência do STF nas decisões anteriores sobre sítio, dizendo que para se tornarem arestos, de alguma maneira vinculantes, ainda faltava tempo de existência ao STF, pois o tribunal ainda era jovem demais para se falar em decisões "perpétuas”, que seriam o caso do aresto (BRASIL, STF, HC1073, p.4-6).

O voto pronunciado pelo ministro Bernardino Ferreira sobre o HC 1073 é o único que não reconhece os argumentos levantados no voto do relator para a mudança da postura do tribunal. Nesse voto, o ministro apenas apresenta releituras de argumentos das decisões anteriores do STF sobre o estado de sítio. Remete à "doutrina da questão política", pelos mesmos motivos que foram elencados no HC $300 .{ }^{22} \mathrm{Fez}$ as mesmas exatas remissões ao direito comparado que haviam sido apresentadas no HC 1063, inclusive com a cópia literal do texto e com a mesma referência a obra de Amancio Alcorta (BRASIL, STF, HC1073, p.7). ${ }^{23}$ Chegou a resguardar que compete ao STF, ainda assim, manter a inviolabilidade da Constituição, de modo que o tribunal poderia intervir

\footnotetext{
20 "Por isso, deixei de apreciar os efeitos do decreto de 12 de novembro e dos que se the seguiram em dezembro e janeiro, os quais, ferindo de frente e ousadamente a Constituição da União, são nulos, e, como todos os atos nulos, desde a raiz, desde o início, nenhum efeito jurídico produzem. Quod ab initio nullum est nullum in jure producit effectum” (BRASIL, STF, HC1073, p.4).

${ }_{21}$ "No habeas corpus n. 1036, impetrado por J. de Medeiros de Albuquerque, em favor do preso político Fortunato de Campos Medeiros, publicado no Diário Oficial de 4 de fevereiro último, enumerei vários casos de regicídio e tentativa de regicídio, (faltanos ainda a palavra presidenticídio), na Europa e na América, nesta metade de século XIX, não seguidos de decretação de estado de sítio. E tão numerosos são eles que me não ocorreram então dois bem frisantes: Sadi-Carnot, na França Republicana, e AbdulAziz, na Turquia. Pouco antes ou logo depois da data desse acórdão, 13 de novembro de 1897, há que acrescentar o fuzilamento de Balta, presidente do Peru, a tentativa contra Cuestas, presidente provisório do Uruguai, o assassinato de Reyna Barrios, presidente de Guatemala, o atentado contra o general Porfirio Dias, contra o presidente eleito de Minas Gerais Dr. Silviano Brandão, etc. Não consta que esses fatos tenham dado lugar a decretos de sítio. No Brasil, porém, onde aos Thraséas foram sempre preferidos os Sejanos, decreta-se assédio, por ter um qualquer Bispo tentado matar o chefe do Poder Executivo (foi o pretexto), e prolonga-se até as vésperas das eleições presidenciais; e durante ele, são perseguidos os homens mais eminentes do partido que sustenta a República... E querem que o Supremo Tribunal Federal seja cúmplice com tão insana ditadura, apoiando a continuação dos efeitos de um sítio inconstitucional e já de há muito declarado extinto pelo Poder Executivo" (BRASIL, STF, HC1073, p.6).

${ }^{22}$ BRASIL. Supremo Tribunal Federal. Habeas Corpus n. 1073. Paciente: João Cordeiro e outros. Relator: Ministro Ribeiro de Almeida. Rio de Janeiro, 30 de março de 1898, 2 de abril de 1898 e 16 de abril de 1898. p.6. Comparar com o já referido no presente trabalho sobre o HC 300, cf. supra, pp.17-19.

${ }^{23}$ Comparar com o já referido no presente trabalho sobre o HC 1063, cf. supra, pp. 27-32.
} 
se fossem tomadas medidas que se excedessem às permitidas constitucionalmente. Nem nisso esse voto divergente inova, uma vez que o argumento se estrutura na mesma forma da ressalva do voto vencedor do HC $410 .{ }^{24}$ No entanto, mesmo com essa verdadeira "colagem" de jurisprudência anterior sobre o qual o ministro Bernardino Ferreira assenta seu voto em posição contrária à virada jurisprudencial do voto da maioria, concedeu a ordem por um detalhe técnico: a Constituição determinava a detenção em local distinto dos presos comuns para os detidos por ato do Executivo no estado de sítio, e a situação fática não apresentava tal separação. Na ilha de Fernando de Noronha, que fora uma ilha-presídio até 1894, persistia um estabelecimento penitenciário, cujas fronteiras não eram bem demarcadas, motivo pelo qual os presos comuns do presídio circulavam livremente pela ilha, denotando que o desterro em Fernando de Noronha era indistinguível da prisão comum no presídio da ilha, constituindo constrangimento ilegal capaz de ensejar a concessão do Habeas (BRASIL, STF, HC1073, p.9-10).

O único voto divergente de fato foi, por isso, o do ministro Ribeiro de Almeida. Neste voto, o ministro se concentra em três pontos argumentativos: questionar a intangibilidade da imunidade parlamentar pelo estado de sítio, alegar a violação da coisa julgada pela identidade de pacientes entre o HC 1063 e 1073, e afastar a interpretação de Bernardino Ferreira sobre o caráter da ilha de Fernando de Noronha. Quanto a imunidade parlamentar, Ribeiro de Almeida entende que o Tribunal excedia sua competência ao criar uma restrição que não estava prevista no texto constitucional, de modo que entendia plenamente constitucional a detenção de parlamentares em meio ao sítio, quando estes estão envolvidos na comoção intestina (BRASIL, STF, HC1073, p.10-11). ${ }^{25}$

Sobre a coisa julgada, o seu argumento é que o HC 1063 já havia resolvido a questão da duração dos efeitos do estado de sítio para aqueles pacientes, sob o fato da cessação do estado de sítio, de modo que o julgamento de Habeas Corpus sobre a mesma matéria, com os mesmos fatos, para os mesmos pacientes, "seria violação do caso julgado". 26

Quanto ao caráter da ilha de Fernando de Noronha, apenas referiu que se os prisioneiros, "por abuso, que deve ser coibido", circulam pela ilha, tal fato não altera o regime legal do restante da ilha, onde residem cidadãos em liberdade (BRASIL, STF, HC1073, p.11). De tal modo, o desterro estaria caracterizado, e não a detenção em local indistinto de prisão para presos comuns. Com base nesses três argumentos, divergiu da maioria

\footnotetext{
${ }^{24}$ Comparar com o já referido no presente trabalho sobre o HC 410, cf. supra, pp. $22-24$.

${ }^{25} \mathrm{O}$ ministro Ribeiro de Almeida também parece indicar que, no seu entendimento, uma tal restrição, além de não ser constitucionalmente positivada, não seria desejável, pois o ministro dá a entender que considera melhor a regulamentação constitucional dos Estados Unidos, que explicita no texto constitucional que a imunidade parlamentar não se estende às prisões por felonia, traição ou perturbação da paz pública, nos termos da Seção 6 da Constituição dos Estados Unidos.

26 "No habeas corpus n. 1063 se decidiu, em 26 de março próximo passado, que o desterro dos pacientes não cessou, em conseqüência do levantamento do estado de sítio; e o mesmo fato - levantamento do estado de sítio - não dá direito aos mesmos pacientes a segundo habeas corpus; seria violação do caso julgado. Se a esse respeito não temos jurisprudência assentada, é caso
} 
no acórdão, sendo seguido por três outros ministros.

Com isso, as decisões do STF sobre o estado de sítio de 1897 terminam, com uma grande virada na jurisprudência, com relação ao que vinha se afirmando desde o HC 300. Essa virada é marcada, sobretudo, pela atitude do tribunal em assumir um papel de defensor das liberdades e garantias individuais frente aos poderes de estado, e do reconhecimento da distinção entre as esferas da decisão política e da decisão jurídica. No entanto, tal postura inovadora não se pode dizer ainda consolidada, à época do julgamento do HC 1073, visto o tamanho do dissenso estabelecido entre os ministros sobre o acórdão.

\section{O ESTADO DE SÍTIO NO GOVERNO HERMES DA FONSECA}

Já no século XX, uma nova situação de estado de sítio provocou uma nova série de decisões do STF sobre a matéria. Em 1910, pouco tempo após a eleição de Hermes da Fonseca ao cargo de Presidente da república, eclodiu uma rebelião de marinheiros, chefiados pelo marinheiro João Cândido, que ficaria conhecida como Revolta da Chibata, em razão de sua principal reivindicação ser a extinção dos castigos físicos, ainda utilizados na Marinha brasileira. A rebelião chegou a seu fim, reprimida dentro da normalidade constitucional, em 27 de novembro daquele ano, ou seja, menos de uma semana após a sua eclosão, com a promessa da extinção dos castigos corporais e com a concessão de uma anistia a todos os marinheiros envolvidos. ${ }^{27}$ No entanto, no dia 28 de novembro daquele ano, o decreto presidencial 8.400, que autorizava a baixa por exclusão "das praças do corpo de marinheiros nacionais cuja permanência no serviço for inconveniente a disciplina”, o que possibilitou a expulsão da marinha de vários dos anistiados envolvidos na Revolta da Chibata, gerando novas tensões entre os praças de marinha e o governo de Hermes da Fonseca.

Na noite de 9 de dezembro, um novo motim de marinheiros ocorre, colocando mais uma vez o governo em conflito com os amotinados. Tal motim levaria o governo de Hermes da Fonseca a sugerir ao Congresso a declaração do estado de sítio, o qual duraria um total de 268 dias (NAUD, 1965a, p. 83). Esse estado de sítio contava com algumas particularidades na redação do ato normativo do Congresso que o declarava:

Art. 10 Ficam declarados em Estado de Sítio até 30 dias o território do Districto Federal e o da comarca de Nitheroy, no Estado do Rio de Janeiro.

Paragrapho unico. Entre as medidas decorrente da promulgação desta lei não se comprehende a suspensão das immunidades parlamentares consignadas pela Constituição da Republica aos membros do Congresso Nacional.

Esse parágrafo único do artigo $1^{\circ}$ do Decreto 2.289 de 1910 apresenta uma primeira resposta da

de se recorrer à dos tribunais dos Estados Unidos da América do Norte, onde não se admite segundo o habeas corpus, quando os fatos alegados são os mesmos" (BRASIL, STF, HC1073, p.11).

${ }^{27} \mathrm{O}$ decreto 2.280, de 25 de novembro de 1910, que consagrou esta anistia, explicitava em seu artigo 10: "É concedida amnistia aos insurrectos de posse dos navios da Armada Nacional, si os mesmos, dentro do prazo que lhes fôr marcado pelo Governo, se submetterem ás autoridades constituidas”. 
legislação brasileira à jurisprudência do STF, como se pode ver. No HC 1073, o STF já havia firmado seu entendimento de que a imunidade parlamentar não era suspensa com as demais garantias pela simples declaração. Aqui vemos que a posição defendida pelo STF acabou sendo explicitada pelo Congresso, para evitar abusos e preservar essa imunidade contra qualquer dúvida interpretativa. ${ }^{28}$

Em meio a esse estado de sítio, declarado no distrito federal (que era constituído essencialmente pela cidade do Rio de Janeiro, à época) e no estado do Rio de Janeiro (cuja capital situava-se no município de Niterói), foram impetrados diversos Habeas Corpus no Supremo Tribunal Federal, e o tribunal se viu na necessidade de aprofundar ainda mais sua jurisprudência sobre o estado de sítio.

O primeiro destes é o HC 2984, impetrado por vários deputados da Assembleia Estadual do Rio de Janeiro. A questão de fundo é que os impetrantes alegavam que o governo, usando do pretexto do estado de sítio, intervinha de maneira a impedir o funcionamento da Assembleia Estadual em questão, uma vez que a força pública federal havia ocupado o prédio da Assembleia e vinha impedindo a entrada dos parlamentares no edifício. Reclamando que tal proceder das forças federais constituía coação ilegal, pois não encontrava justificativa legal no ato de declaração do estado de sítio, os deputados pediam ao STF que concedesse o Habeas Corpus (BRASIL, STF, HC2984, p.1). A questão era complexa, pois a formação exata da Assembleia Estadual do Rio de Janeiro era incerta, vez que, naquele ano, em meio às turbulências da eleição de 1909, realizada sob sérias acusações de fraude (SILVA e CARNEIRO, 1975b, p. 99-111), dois grupos declaravam-se a assembleia eleita, e pretendiam empossar diferentes Presidentes do Estado para o Rio de Janeiro. A tese sustentada pelo governo é a de que não houvera coação ilegal comprovada ou que, se houvera, esta já cessara, e de que os pacientes não comprovaram ser deputados, além de alegação da incompetência do STF sob o argumento da "questão política". A resposta do STF a essa tentativa de reavivar a "doutrina da questão política", para restringir sua competência, foi incisiva no sentido de que se reconheciam incompetentes para as questões que fossem de fato estritamente políticas, mas por outro lado ao tribunal cumpria a função de defender os direitos e garantias individuais. ${ }^{29} \mathrm{~A}$ solução para distinguir a linha da questão estritamente política constrói uma espécie de prática de decidir, na dúvida, por tutelar o direito

\footnotetext{
${ }^{28}$ O parágrafo único foi inserido por uma emenda no senado, de autoria do Senador Lauro Sodré, após um longo debate com o Senador Ruy Barbosa, em que este último destacava o histórico de abusos cometidos em meio ao estado de sítio, contra os quais recorrera tantas vezes ao Habeas Corpus. Mesmo com a emenda do parágrafo único, Ruy Barbosa ainda votou contra (NAUD, 1965 b, p. 62-66).

29 "Certamente aceitável, se não essencial ao regimen da separação e independência dos poderes públicos, como é, a doutrina de que as questões essencialmente políticas, escapam à competência do Judiciário e devem ficar ao critério dos poderes políticos, a dizer, o Legislativo e o Executivo, respectivamente; isso não obstante, competindo, concorrentemente e como função indiscutível do judiciário, amparar os direitos individuais, garantir o seu exercício e fazer reparar qualquer lesão de tais direitos; se torna, não raro, assáz difícil bem distinguir até onde se possa deixar livre a ação dos poderes políticos em dados assuntos, sem o sacrifício dos direitos individuais, que ao Judiciário cumpre, privativamente, amparar" (BRASIL, STF, HC2984, p.2).
} 
individual e de só reconhecer a limitação quando a "questão política" fosse a totalidade da matéria. ${ }^{30}$ O STF não ingressa, ainda assim, na questão de qual assembleia ou Presidente do Estado era legítimo, o que seria de fato a "questão política" estrita (BRASIL, STF, HC2984, p.4-6). Como o tribunal entendeu as demais questões, fáticas, em favor do alegado pelos pacientes, concedeu a ordem, por maioria. Em nenhum momento discorrem os ministros sobre a natureza do sítio em questão, mas é notável que tenham afastado com tamanha clareza a "doutrina da questão política", sendo este acórdão o marco em que a questão política deixa de ser empecilho ao acesso do writ de Habeas Corpus para a defesa dos direitos, graças à prática de decidir, na dúvida, em favor da tutela dos direitos individuais quando estes se encontram violados.

Essa prática de decidir a dúvida na delimitação da questão política em favor do acesso à tutela dos direitos, entretanto, ainda não seria plenamente unânime e assentada na jurisprudência do STF. No Habeas Corpus 3061, que julgava o exato mesmo caso, como reconhecia o próprio acórdão, o voto vencedor essencialmente apenas reproduzia e desenvolvia o já apresentado no acórdão. No entanto, chama atenção o voto divergente do acórdão, de autoria do ministro Godofredo Cunha. Nele, o ministro reaviva a "doutrina da questão política”, entendendo que o STF estaria impedido de decidir a questão da dualidade de assembleias por esta ser uma "questão política", a qual cabia ser decidida no máximo pelo Presidente da República por meio de intervenção federal. O que chama a atenção, no entanto, é que o voto não reconstrói uma "doutrina da questão política” apenas para a intervenção, mas também para o sítio (inclusive em face de que Niterói, então capital do estado do Rio de Janeiro, se encontrava em ambas as situações simultaneamente):

O poder excepcional do Governo, em matéria de intervenção, como em matéria de estado de sítio, exercido sob o exame imediato do Poder Legislativo, escapa à intromissão judicial. O Governo nestes casos representa o parlamento. A substituição condicional do segundo pelo primeiro resulta da necessidade de assegurar prontamente a defesa interior ou a ordem material do Estado.

A intervenção pode certamente gerar casos judiciais. O decreto de intervenção, como o de estado de sítio, expedido pelo Poder Executivo, quando, na ausência do Congresso, corre a Nação ou qualquer Estado iminente perigo, tem o caráter de um ato de soberania, completamente independente dos atos ulteriores necessários para sua execução (BRASIL, STF, HC3061, p.9).

Esse voto do ministro Godofredo Cunha não traz nenhum elemento novo à velha "doutrina da questão política”, a não ser a explicitação da aplicação de tal doutrina para a intervenção federal, e é uma das últimas representações de tal doutrina a resistir à tendência que ia se estabelecendo na jurisprudência do STF. Conforme

\footnotetext{
30 "E daí sucede que, a despeito da verdade da aludida doutrina, na prática da jurisprudência a incompetência do Judiciário, nas matérias políticas, só tem sido de regra, quando o caso sujeito é, pela sua natureza e objeto, da atribuição exclusiva de dado poder político, nos termos expressos da Constituição" (BRASIL, STF, HC2984, p.2). Essa decisão também faz referência à prática semelhante nas cortes dos Estados Unidos, em relação à questões políticas.
} 
o tribunal desenvolvia as questões referentes ao estado de sítio, na mesma medida em que se estabilizava e amadurecia como instituição, ia se afirmando progressivamente uma tendência de realizar controles cada vez mais amplos da discricionariedade política em face da garantia dos direitos individuais. Cada vez mais, vinha o STF reconhecendo uma esfera jurídica fundamental que não era atingível, a não ser em situações muito restritas, pela discricionariedade política.

Ainda assim, mesmo com a "questão política" agora sendo entendida no sentido mais estrito pelo STF, a corte ainda havia de reconhecer que certas matérias eram apenas políticas, não sendo diretamente pertinentes à tutela dos direitos e, portanto, lhe escapavam.

Ainda dentro da presidência de Hermes da Fonseca, houve uma série de decretos de estado de sítio, em 1914. Formulados apenas com remissões vagas à desordem pública, como "características de comoção intestina", "para evitar os efeitos da anarquia" e "subsistirem ainda os propósitos subversivos dos agitadores que querem sobrepor à vontade da Nação, manifestada nas urnas, as suas ambições" (NAUD, 1965b, p. 73), o que indica que o estado de sítio, declarados nas cidades de Rio de Janeiro, Niterói e Petrópolis, se direcionava contra opositores eleitorais de Hermes da Fonseca. De fato, o Senador Ruy Barbosa, que fora o candidato derrotado nas eleições presidenciais, denuncia o caráter deste sítio, repetidamente prorrogado, como forma do Executivo controlar o parlamento e silenciar a oposição, mantendo uma exceção quase permanente (NAUD, 1965b, p. 74-77).

A questão política retorna no caso do Habeas Corpus 3527, impetrado por detidos neste estado de sítio, que pediam ao tribunal que declarasse a inconstitucionalidade da própria norma de declaração do estado de sítio, por este não ter sido declarado de modo conforme ao previsto na Constituição de 1891. O STF, porém, se negou a intervir no que julgava ser o espaço de discricionariedade dos demais Poderes, em razão da independência consagrada na divisão dos Poderes pela Constituição. ${ }^{31}$ Desta maneira, mostra-se o outro lado da jurisprudência da doutrina da questão política restrita, qual seja, o reconhecimento de um espaço em que não cabe ao Poder Judiciário intervir sobre as decisões discricionárias de outros poderes, pois essas se movem politicamente dentro do quadro normativo, ao passo que ao Judiciário cabe apenas tutelar aquele direito afetado por uma consequência normativa que esteja demonstradamente fora do quadro, sem avaliar a conveniência das medidas reservadas ao juízo político dos outros poderes. A questão do debate, portanto, se cingia a observar se o juízo pedido pelos impetrantes dizia respeito à conveniência material ou se dizia respeito à ausência de previsão constitucional que fundamentasse o ato de coerção. No caso, o STF entendeu que se lhe pedia para adentrar ao juízo de conveniência material, pelo que se declarou incompetente para a decisão.

\footnotetext{
31 "Considerando que se é verdade, como é, que ao Supremo Tribunal Federal, cabe o exame dos atos dos dois outros poderes, quando argüidos de lesivos de direitos individuais pelos vícios de ilegalidade ou inconstitucionalidade, nem por isto poderá o tribunal, estender o uso dessa atribuição até ao ponto de julgar do mérito de atos que envolvem a própria independência de cada
} 
Por fim, outro acórdão referente ao sítio de 1910 a ser analisado mais detalhadamente é o HC 3536, no qual o Senador Ruy Barbosa é tanto impetrante quanto paciente. O caso específico é o que distingue essa decisão de outras tantas sobre a matéria do estado de sítio. Nesta decisão o Habeas Corpus não está sendo utilizado como remédio para tutelar a liberdade de locomoção propriamente dita, mas sim para tutelar a liberdade de expressão. Aqui, o Senador Ruy Barbosa pedia que cessasse constrangimento ilegal constituído na proibição imposta pelo chefe de polícia do Rio de Janeiro, em meio ao estado de sítio, a que os jornais publicassem debates no Senado nacional. O que Ruy buscava era publicar no jornal O Imparcial um discurso que proferira no Senado justamente contra a prorrogação do estado de sítio. A decisão concedeu a ordem, a partir do fundamento da não suspensão da imunidade parlamentar no estado de sítio (a manutenção da imunidade parlamentar, lembre-se, era já expressa na declaração do estado de sítio em questão) e de que a imunidade parlamentar englobava o direito constitucional de ver publicados seus discursos, pois a própria natureza do cargo representativo exige a publicidade da palavra (BRASIL, STF, HC3536, p.2). Assim, mais uma vez o STF afirmou, agora com a vantagem do texto explícito da lei, a intangibilidade da imunidade parlamentar pelo estado de sítio, o que constitui a afirmação final de um importante desenvolvimento histórico, no que diz respeito ao governo constitucionalmente limitado, no Brasil. Tanto mais interessante pela amplitude conferida a essa imunidade parlamentar, podendo mesmo não ser afetada pela censura, que seria constitucional para a opinião daqueles que não os parlamentares, no estado de sítio (BRASIL, STF, HC, p.2).

\section{A REFORMA CONSTITUCIONAL DE 1926 E SUA RELAÇÃO COM O ESTADO DE SÍTIO}

Além dos estados de sítio discutidos nos acórdãos anteriormente analisados, muitas outras declarações de estado de sítio ocorreram ao longo da República Velha, mas que não se analisam no presente trabalho por não terem provocado decisões significativas na jurisprudência do STF. No entanto, cabe fazer alguns apontamentos sobre o uso do estado de sítio na década final da República Velha, em razão de que a regulamentação constitucional do sítio foi alterada, em 1926, por uma emenda constitucional que alterou parte considerável da Constituição de 1891. Há que se ter em mente também que, de 1930 em diante, esta Constituição acabou totalmente desgastada, sendo rompida definitivamente no governo provisório de Getúlio Vargas com a

um dos três poderes, todos existindo e devendo funcionar dentro dos limites postos pela Constituição" (BRASIL, STF, HC3257, p.1). 
promulgação de uma nova Constituição em 1934. Assim, passemos por algumas breves observações sobre o uso do estado de sítio a partir de 1922.

Em 5 de julho de 1922, em resposta a rebelião de oficiais militares no Forte de Copacabana, a qual fica ria conhecida como o episódio dos "18 do Forte", o governo do presidente Epitácio Pessoa declararia um estado de sítio que duraria 132 dias (NAUD, 1965a, p. 84). O instituto do estado de sítio, que foi utilizado em quase todos os governos da República até então, com menor ou maior intensidade nas medidas repressivas, começaria uma escalada, sendo declarado com cada vez maior frequência, em meio a crescentes comoções intestinas.

A presidência de Artur Bernardes, sucessor de Epitácio Pessoa, seria de tal maneira marcado pelo estado de sítio que 1.287 dias decorreram sob estado de sítio declarado em algum ponto do território nacional (NAUD, 1965b, p. 121). Sendo que o mandato presidencial era quadrienal, de acordo com a Constituição da época (ou seja, o tempo total do mandato presidencial era de 1.460 dias), a duração total do estado de sítio soma $88,15 \%$ da presidência de Artur Bernardes. Aqui, o estado de sítio, medida inegavelmente excepcional, ia se convertendo em normalidade na prática do governo. Mesmo com a faculdade das medidas repressivas para o sítio, o Executivo nacional não alcançava mais conter as desordens e perturbações da paz que se agravavam. O Congresso Nacional concedeu a prorrogação e aprovou as medidas de todos os estados de sítio decretados pelo Executivo, no entanto, pois ocorriam continuamente episódios de rebelião, especialmente de oficiais militares de baixo escalão, por todo o país (NAUD, 1965b, p. 129). No entanto, já em 1925, a continuidade dos estados de sítio e o consequente enfraquecimento institucional do Congresso frente ao Executivo já levantava queixas dos parlamentares, ao ponto de ser chamado, em meio a sessão da câmara, de "estado de sítio crônico e, já agora, manifestamente inconstitucional" por um deputado (NAUD, 1965b, p. 137).

Deste modo, a situação em 1926 é de um país em grandes conflitos internos, sofrendo de um grande desgaste institucional, e no qual há simultaneamente uma desconfia aguda das medidas de exceção em geral convivendo com a necessidade de um resguardo da ordem constitucional mais efetivo do que vinha ocorrendo. É diante desse quadro que o Congresso nacional aprova a Emenda Constitucional de 3 de setembro de 1926.

A Emenda Constitucional modificava vários artigos da Constituição de 1891 para desenhar uma ampla reforma no ordenamento constitucional: criava mais causas para a possível incidência da intervenção federal, alterações na competência privativa do Congresso Nacional, na competência da Justiça Federal e no direito de propriedade sobre minas. Quanto ao estado de sítio e a comoções intestinas, importante destacar os seguintes aspectos da reforma:

1. Com o fim da competência privativa do Congresso para mobilizar a guarda nacional ou milícia cívica, esta instituição, de natureza militar paralela, é extinta em definitivo da estrutura institucional de segurança brasileira. Levando em conta a situação de recorrentes insurreições armadas, inclusive por parte de 
militares amotinados, tal medida elimina definitivamente uma instituição que só poderia contribuir para aumentar a instabilidade e a violência interna, àquela altura da República.

2. A competência privativa do congresso para legislar sobre licenças, aposentadorias e reformas, que pode representar o reconhecimento da comoção gerada pelas demissões arbitrárias em meio ao sítio ou como forma de repressão dos seus 'causadores', conforme haviam ocorrido nos casos das revoltas da Armada e da Chibata.

3. A criação, no $\$ 5^{\circ}$ do art. 60 , de uma proibição de qualquer recurso judiciário contra "a declaração do estado de sitio e a verificação de poderes, o reconhecimento, a posse, a legitimidade e a perda de mandato dos membros do Poder Legislativo ou Executivo, federal ou estadual". Nisso, a Emenda Constitucional de 1926 está claramente fazendo uma opção política definitiva, em resposta às continuadas discussões sobre a "doutrina da questão política" no STF. No mesmo parágrafo, ainda, constitucionalizou a proibição, antes constante do regimento interno do STF, de conhecer dos atos praticados em razão do estado de sítio enquanto na vigência destes, estendo aos demais tribunais essa vedação: "assim como, na vigencia do estado de sitio, não poderão os tribunaes conhecer dos actos praticados em virtude delle pelo Poder Legislativo ou Executivo".

Assim, a reforma era destinada a confrontar questões importantes da crise política que o país atravessava, e se focou sobretudo na intervenção federal e na definição dos conflitos que causavam controvérsias políticas. Especialmente quanto ao sítio, verifica-se nessa reforma a consagração da "doutrina da questão política", construída na jurisprudência do STF ao redor do estado de sítio, chegando a ser finalmente inscrito no texto constitucional pelo Congresso, como poder constituinte reformador, uma regra da questão política que abrangia, ao fim e ao cabo, a interpretação da doutrina da questão política restrita então consagrada no STF. Deste modo, esse aspecto da reforma, alterando o estado de sítio, pode ser visto como o ápice de um grande debate jurisprudencial que foi se construindo ao longo da República Velha sobre o papel do controle judiciário em meio ao estado de sítio.

Toda a reforma de 1926, no entanto, não conseguiu realizar o fim último do estado de sítio, isto é, a defesa da ordem constitucional estabelecida, visto que as insurreições e rebeliões continuaram por todo o país, até culminarem na Revolução de 1930, que instituiria o governo provisório de Getúlio Vargas, o qual se estendeu até 1934, quando a Constituição de 1891, fatalmente desgastada pela realidade social turbulenta do país, é rompida de maneira final com a promulgação de uma nova Constituição, em 1934, inaugurando um novo período constitucional no país.

\section{CONCLUSÕES}


A partir da metodologia elaborada, buscava-se a descrição de uma linha jurisprudencial do STF sobre o estado de sítio sob a Constituição de 1891. O trabalho se orientou pelo conceito de estado de sítio como uma forma pela qual uma Constituição regulamenta o exercício de poderes excepcionais em meio a uma emergência para proteger o Estado ou a ordem constitucional, e que se caracteriza pela declaração explícita por meio de algum instrumento normativo dos poderes constituídos e que utiliza da restrição ou suspensão de certos direitos fundamentais ou garantias constitucionais. Apontou-se a origem francesa deste instituto, destinada originalmente a emergências militares, mas que se expandiu para englobar comoções internas, havendo assim o estado de sítio efetivo, de motivação militar, e o estado de sítio fictício, de motivos políticos.

Observou-se a regulamentação de competências própria da Constituição de 1891, que previa a sua declaração preferencialmente pelo Congresso ou, subsidiariamente para o Executivo, com medidas limitadas. Apresentou-se a sistemática constitucional do juízo político do Congresso, a ser lançado sobre as medidas excepcionais do Executivo após o fim da emergência, e que podia ensejar a responsabilidade do Presidente da República.

Com a análise da jurisprudência do STF apresentou-se a evolução da "doutrina da questão política", questão que havia sido central no desenvolvimento da linha de decisão do tribunal sobre o estado. Em um primeiro momento, o STF se apresenta decidido a negar as ordens de Habeas Corpus pela convicção de que não podem decidir sobre os efeitos do estado de sítio por se tratar este de questão política que escaparia a ala do Judiciário. No entanto, pouco a pouco, o tribunal vai reconhecendo um âmbito de direitos fundamentais que não podem ser afetados pela decisão política discricionária no estado de sítio, passando a exercer um crescente controle de constitucionalidade. Ao final do desenvolvimento dessa evolução jurisprudencial, o STF delineia o que se pode chamar de doutrina da questão política restrita, em que o tribunal se entende incompetente para decidir a questão puramente política, mas concede a tutela dos direitos fundamentais violados por atos que excedem as normas regulamentadoras do sítio. A linha da questão política, que antes abrangia todo o caso e tornava-o impenetrável ao Judiciário, vai sendo recuada interpretativamente até restar limitado a um núcleo puramente político, chegando à prática interpretativa final de delimitar esta linha em favor da proteção do direito, quando havia dúvida. Este é o principal desenvolvimento na jurisprudência, a evolução da doutrina da questão política ampla em direção à uma doutrina da questão política estrita. Esse desenvolvimento acabará sendo incorporado ao texto constitucional, na Emenda Constitucional de 1926, que consagra a doutrina da questão política estrita.

Também, partindo de uma compreensão da detenção no estado de sítio como sendo uma forma de medida asseguradora do processo, determinavam que o detido que fosse encaminhado à prisão indevida ou contra o qual não coubesse um processo criminal adequado fosse liberado. Aos poucos, a detenção e o desterro 
vão passando de quadros normativos abertos a decisão discricionária do Executivo para quadros normativos mais estreitos, graças a interpretação constitucional, que cada vez mais restringia as medidas repressivas àquelas estritamente regulares juridicamente.

Destaca-se também o papel do STF em construir, a partir da virada do paradigma do Habeas Corpus 1073 em estabelecer duas restrições aos poderes excepcionais: (1) A intangibilidade da imunidade parlamentar pelos atos de sítio, que vai se ver repetida e estendida à liberdade de expressão do parlamentar no Habeas Corpus 3536. (2) A limitação temporal da duração das medidas repressivas iniciadas durante o estado de sítio. Inicialmente muito resistida pelo STF, acabou por consolidar-se na tradição jurídica brasileira o reconhecimento da cessação automática das medidas repressivas com o fim do estado de sítio.

Em suma, o que podemos ver de toda a evolução jurisprudencial analisada é que a jurisprudência do STF sobre estado de sítio evoluiu, de modo geral, de uma posição inerte que reconhece amplo espaço para discricionariedade do Executivo no estado de sítio para uma postura cada vez mais assertiva de controle jurídico dos atos de sítio em prol dos direitos e garantias dos indivíduos, porém sem jamais aceitar a interferência dentro do espaço de discricionariedade política delimitado pela regulamentação constitucional. Esta postura se desenvolveu de maneira progressivamente mais crítica aos abusos recorrentes pelo Executivo dos sucessivos estados de sítio, na medida em que o tribunal amadurecia e assentava sua independência com relação aos outros Poderes da República, e assumia uma identidade como órgão protetor dos direitos fundamentais e das garantias constitucionais. No entanto, apenas o controle do STF, mesmo nos moldes de doutrina da questão política restrita e de proteção de direitos, não foi capaz de evitar a banalização do estado de sítio, consolidada no "estado de sítio crônico" na década final da República Velha. Nem mesmo sendo constitucionalizada textualmente a posição do tribunal no ápice desta evolução, a prática do estado de sítio deixou-se resolver de maneira adequada às funções deste, na medida em que a regulamentação do estado de exceção no estado de sítio pretende garantir a ordem constitucional e assegurar o retorno à normalidade, ao passo que, ao fim e ao cabo, o retorno à normalidade já estava comprometido na década final da república velha, bem como a excepcionalidade se aprofundaria ao longo do governo provisório de Vargas, culminando com a ruptura definitiva da Constituição de 1891, incluindo sua regulação de sítio, pela promulgação da Constituição de 1934, a qual ainda assim absorveu parte considerável da tradição constitucional de sítio, desenvolvida ao longo da linha jurisprudencial que foi aqui analisada.

THE SUPREME FEDERAL COURT AND THE STATE OF SIEGE IN THE FIRST
BRAZILIAN REPUBLIC: THE JURISPRUDENCE OF THE SUPREME FEDERAL
COURT ABOUT STATE OF SIEGE, FROM THE BEGINNING OF THE REPUBLIC 


\title{
TO THE REVOLUTION OF 1930 (1893-1930).
}

\begin{abstract}
The present work has as its theme the constitutional jurisdiction about the state of siege in Brazil, along the First Brazilian Republic. The question is whether it is possible to find a line that gives unity to the comprehension of the state of siege in the jurisprudence of the Brazilian Supreme Federal Court (Supremo Tribunal Federal) in the period between 1891 and 1930. The methodology is inductive, through the analysis of selected Supreme Court decisions in order to seek, from the specific cases, a general understanding of the constitutional jurisprudence. It was the hypothesis that the Supreme Court has maintained a single line in its jurisprudence during the analysis period, exerting judicial control over the constitutionality of the declaration of the state of siege. Such hypothesis was partly confirmed throughout the research, concluding that the jurisprudence of the Supreme Federal Court on siege state undergoes a gradual evolution over the period, towards a restricted conception of the political issue and an attitude of protection to individual rights and legal guarantees. In final considerations, the present study contributes to the comprehension of the relation between state of siege and fundamental rights in the brazilian tradition.
\end{abstract}

Keywords: First Brazilian Republic. State of Siege. Brazilian Supreme Federal Court. Brazil. Political Issue.

\section{REFERÊNCIAS}

AGAMBEN, Giorgio. Estado de Excepción. (Trads. Flávia Costa e Ivana Costa). 4ª ed. Buenos Aires: Adriana Hidalgo, 2010.

ALCORTA, Amancio. Las Garantias Constitucionales. 1ª ed. Buenos Aires: Libraurue Générale, 1881.

BARBOSA, Ruy. Atos Inconstitucionais. 3a ed. Campinas: Russell, 2010.

_O Estado de Sítio: sua natureza, seus efeitos e seus limites. Rio de Janeiro: Companhia Impressora, 1892.

BRASIL. Constituição (1891). Constituição da República dos Estados Unidos do Brasil: promulgada em 24 de fevereiro de 1891. Organização do texto: Walter Costa Porto. Brasília: Senado Federal, Subsecretaria de Edições Técnicas, 2012.

Decreto 2.289, de 12 de dezembro de 1910. Câmara dos Deputados. Disponível em: <http://www2.camara.leg.br/legin/fed/decret/1910-1919/decreto-2289-12-dezembro-1910-586778-

publicacaooriginal-110425-pl.html >. Acesso em: 16 ago. 2015.

Decreto 2.737, de 11 de dezembro de 1897. Senado. Disponível em:

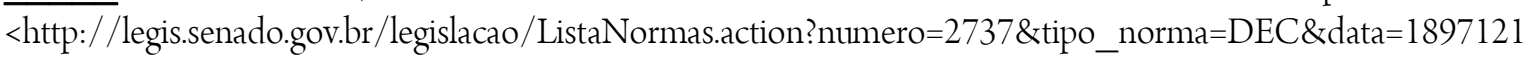
$1 \&$ link $=\mathrm{s}>$. Acesso em 16 ago. 2015

Decreto 2.810, de 31 de Janeiro de 1898. Senado. Disponível em: <http://legis.senado.gov.br/legislacao/ListaNormas.action?numero=2810\&tipo_norma=DEC\&data=1898013 $1 \&$ link $=\mathrm{s}>$. Acesso em: 16 ago. 2015

Decreto do Poder Legislativo 456, de 12 de Novembro de 1897. Senado. Disponível em: <http://legis.senado.gov.br/legislacao/ListaNormas.action?numero=456\&tipo_norma=DEC\&data=18971112 \&link=s>. Acesso em: 16 ago. 2015.

Decreto no 791 de 10 de Abril de 1892. Coleção de Leis do Brasil - 1892. Vols. I, pt. 2.. p.173. Disponível em :<http://www2.camara.leg.br/legin/fed/decret/1824-1899/decreto-791-10-abril-1892-506799- 
publicacaooriginal-1-pe.html>. Acesso em: 18 de Julho de 2015.

BRASIL. Supremo Tribunal Federal. Habeas Corpus n. 300. Paciente: Eduardo Wandenkolk e outros. Relator: Ministro Costa Barradas. Rio de Janeiro, 27 de abril de 1892. Disponível em:

<http://www.stf.jus.br/arquivo/cms/sobreStfConhecaStfJulgamentoHistorico/anexo/HC300.pdf〉. Acesso em: 16 jul. 2015.

Supremo Tribunal Federal. Habeas Corpus n. 406. Paciente: David Ben Obill e outros. Relator: Ministro Barros Pimentel. Rio de Janeiro, 16 de Agosto de 1893. Disponível em:

<http://www.stf.jus.br/arquivo/cms/sobreStfConhecaStfJulgamentoHistorico/anexo/HC406.pdf>. Acesso em: 15 jul. 2015

Supremo Tribunal Federal. Habeas Corpus n. 410. Paciente: Mário Aurélio da Silveira. Relator: Ministro José Higyno. Rio de Janeiro, 16 de Agosto de 1893. Disponível em:

<http://www.stf.jus.br/arquivo/cms/sobreStfConhecaStfJulgamentoHistorico/anexo/HC410.pdf>. Acesso em: 16 jul. 2015.

Supremo Tribunal Federal. Habeas Corpus n. 415. Paciente: Eduardo Wandenkolk e outros. Relator: Ministro Ovídio de Loureiro. Rio de Janeiro, 02 de setembro de 1893. Disponível em:

$<$ http://www.stf.jus.br/arquivo/cms/sobreStfConhecaStfjulgamentoHistorico/anexo/HC415.pdf>. Acesso em: 16 jul. 2015.

Supremo Tribunal Federal. Habeas Corpus n. 1063. Paciente: João Cordeiro e outros. Relator: Ministro Bernardino Ferreira. Rio de Janeiro, 03 de março de 1898 e 26 de março de 1898. Disponível em:

<http://www.stf.jus.br/arquivo/cms/sobreStfConhecaStfjulgamentoHistorico/anexo/HC1063.pdf>. Acesso em: 16 jul. 2015.

Supremo Tribunal Federal. Habeas Corpus n. 1073. Paciente: João Cordeiro e outros. Relator: Ministro Ribeiro de Almeida. Rio de Janeiro, 30 de março de 1898, 2 de abril de 1898 e 16 de abril de 1898. Disponível em: <http://www.stf.jus.br/arquivo/cms/sobreStfConhecaStfjulgamentoHistorico/anexo/HC1073.pdf>. Acesso em: 16 jul. 2015.

Supremo Tribunal Federal. Habeas Corpus n. 2984. Paciente: Assembleia Legislativa do Rio de Janeiro. Relator: Ministro Amaro Cavalcanti. Rio de Janeiro, 4 de janeiro de 1911. Disponível em: <http://www.stf.jus.br/arquivo/cms/sobreStfConhecaStfJulgamentoHistorico/anexo/HC2984.pdf> Acesso: 23 ago. 2015

Supremo Tribunal Federal. Habeas Corpus n. 3061. Paciente: Modesto Alves Moreira de Melo \& Assembleia do Rio de Janeiro. Relator: Ministro Canuto Saraiva. Rio de Janeiro, 29 de julho de 1911. Disponível em: <http://www.stf.jus.br/arquivo/cms/sobreStfConhecaStfJulgamentoHistorico/anexo/HC3061.pdf> Acesso em 17 jul. 2015.

Supremo Tribunal Federal. Habeas Corpus n. 3527. Paciente: José Eduardo de Macedo Soares e outros. Relator: Ministro Amaro Cavalcanti. Rio de Janeiro, 15 de abril de 1914. Disponível em:

$<$ http://www.stf.jus.br/arquivo/cms/sobreStfConhecaStfJulgamentoHistorico/anexo/HC3527.pdf>. Acesso em: 16 jul. 2015.

Supremo Tribunal Federal. Habeas Corpus n. 3536. Paciente: Ruy Barbosa. Relator: Ministro Oliveira Ribeiro. Rio de Janeiro, 6 de maio de 1914. Disponível em:

<http://www.stf.jus.br/arquivo/cms/sobreStfConhecaStfjulgamentoHistorico/anexo/HC3536.pdf>. Acesso em: 16 jul. 2015.

FRIEDRICH, Carl Joachim. Constitutional Government and Democracy. $4^{a}$ ed. Waltham: Blaisdell Publishing Company, 1968.

HESSE, Konrad. Elementos de Direito Constitucional da República Federal da Alemanha. Trad. Luís Afonso Heck. Porto Alegre: Sergio Antonio Fabris, 1998. 
NAUD, Leda Maria Cardoso. Estado de Sítio (2a Parte: 1910-1922). Revista de Informação Legislativa, Brasília, v.2, n.6, p.61-88, jun. 1965. Disponível em: <http://www2.senado.leg.br/bdsf/item/id/182495>. Acesso em: 19 de Agosto de 2015.

Estado de Sítio (3a Parte: 1922-1930). Revista de Informação Legislativa, Brasília, v.2, n.7, p.121-148, set.1965. Disponível em: <http://www2.senado.leg.br/bdsf/item/id/180648>. Acesso em: 22 de agosto de 2015.

SILVA, Hélio e Maria Cecília Ribas CARNEIRO. História da República Brasileira: Nasce a República (18881894). Vol. 1. São Paulo: Três, 1975.20 vols.

vols.

História da República Brasileira: Luta pela Democracia (1911-1914). Vol. 3. São Paulo: Três, 1975. 20

Trabalho enviado em 05 de maio de 2016.

Aceito em 31 de agosto de 2016. 